\title{
THE INCORPORATION OF FORMATE-C 14 INTO THE
}

NUCLEIC ACIDS OF RATS WITH REGENEKATING LIVER AND

NOVIKOFF HEPATOMA.

by

John Charles Nixon

A THESIS SUBWITLED IN PARTIAL FULFILMENT OF THE REQUIRENENTS FOR THE DEGREE OF

MASTER OF SCIENCE

in the Department

of

Biochemistry

We accept this thesis as conforming to the standard required from candidates for the degree of MASTER OF SCIENCE.

Members of the Department of Biochemistry

The University of British Columbia April, 1958. 


\section{ABSTRACT}

A comparison has been made of the formate-c ${ }^{14}$ incorporation into the nucleic acid purines and thymine of regenerating rat $l$ iver and Novikof $f$ hepatoma in vivo. The effects of these tissues on one another, and on the host tissues has been studied. The utilization of formate by the nucleic acids of Novikoff hepatoma and regenerating rat liver was not significantly altered in animals containing both of these rapidly dividing tissues. The results indicated that the demand for formate by one of the rapidly growing tissues did not lower the uptake of formate by the nucleic acids of the other tissue. Fur thermore it was indicated that nucleic acid synthesis in regenerating liver did not alter the synthesis of nucleic acids in other tissues. Regenerating liver and Novikoff hepatoma had no effect on the nucleic acid metabolism of the host tissues of animals bearing one or both of these tissues. These results are not completely in agreement with those reported in the 1 iterature.

In a preliminary experiment a radioactive suspension of Novikoff hepatoma was transplanted into rats. Twenty percent of the injected radioactivity was recovered in the urine during the first 24 hours of tumor growth. The specific activities of the nucleic acid bases of the tumor, obtained after 24 hours of growth, were negligible. 
These findings indicated that the nucleic acids of the donor tumor suspension were not utilized in the synthesis of the nucleic acids of the growing tumor. 


\section{ACKNOWLEDGEENTS}

The personal assistance of the National Research Council in the form of two Graduate Medical Research Fellowships is gratefully acknowledged.

The author also wishes to express his appreciation of the assistance and counsel given by Dr. S. H. Źbarsky during the course of this research.

Mrs. V. Creelman, Miss B. S. Findlay, Miss L. Maddex, and Miss M. M. Wei of the Department of Biochemistry, University of British Columbia, kindly performed the tumor transplantations.

The author acknowledges the assistance and advice of Dr. H. E. Taylor, Head of the Department of Pathology, and Dr. K, Cole, Department of Biology and Botany, University of British Columbia, in the histological preparation of the tumor tissue prior to the mitotic counts.

This research was supported by grants from the National Research Council and the National Cancer Institute of Canada. 
1. Studies Comparing Tumor and Non-tumor

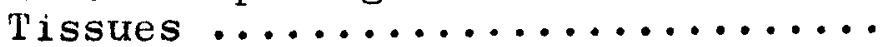

II. The Effects of Tumor on Host $T$ issues.

III. Studies of Regenerating Liver ......

IV. Metabolic Interrelations of Regenerating Liver and Tumor Tissues.......

V. The Riresent Investigation .......... 10

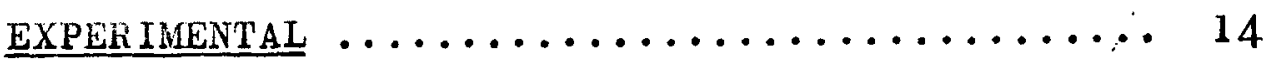

A. METHODS.

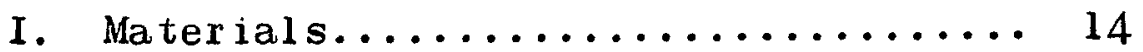

II. Partial Hepatectomies............. 14

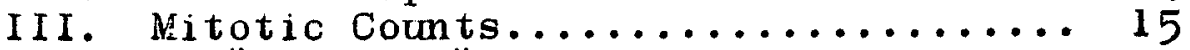

1. "standard" Technique............. 17

2. "Squash" Technique............ 17

IV. Collection of Expired $\mathrm{CO}_{2} \ldots \ldots \ldots \ldots \ldots 17$

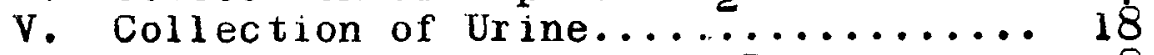

VI. Isolation of Pur ines and Pyrimidines. 18

VII. Ul traviolet Spectrophotometry........ 19

VIII. Radioactive Counting Procedures...... 20

B. RESULTS.

I. Mitotic Counts.................. 22

II. Formate Incorporation into the Nuc-

leic Acids of Tissues of Partially Hepatectomized and Tumor-Bearing

Rats...................... 23

i. Fartially hepatectomized rats.... 25

ii. Tumor-bearing rats............ 26

iii. Partially hepatectomized-tumorbearing rats............... 27

Iv. Excretion of Radio activity in the Expired $\mathrm{CO}_{2}$ and Urine...... 29

v. Tumor-bearing Fats Injected with Formate-cl4 followed by Partial He patec tomy................. 33

II. Transplanted Radio active Novikoff hepatoma................... 35

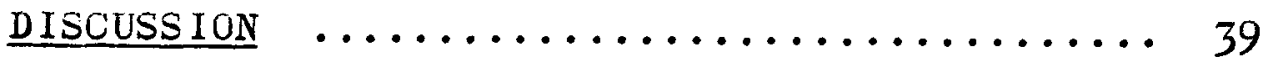

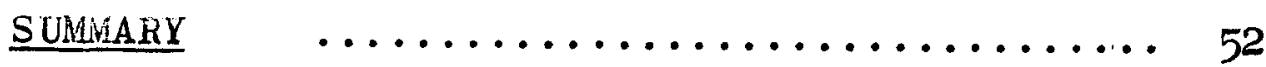

BIBLIOGRAPHY $\ldots \ldots \ldots \ldots \ldots \ldots \ldots \ldots . \ldots \ldots$ 
1. Relative specific activities of nucleic acid purines of 1 iver...(.t. fa.ce.)...

2. Relative specific activities of nucleic acid purines of Novikoff hepatoma................. face)... 26

3. Relative specific activities of nucleic acid purines of spleen. (to. face.)...

4. Relative specific activities of nucleic acid purines of intestinal mucosa.. ............... (to follow).....

5. Relative specific activities of DNA thymine of liver, Novikoff hepatoma, spleen and intestinal mucosa.(t.o. face) 28

6. Relative specific activities of nucleic acid purines and thymine of tumorbearing delayed hepatectomized and tumor-bearing control animals.(.t.o. face) 34 


\section{TABLES}

Page

I Mitotic indices of Novikoff hepatoma...... 23

II Time relationship of procedures.(to. follow). 24

II Radioactivity excreted in expired $\mathrm{CO}_{2}$ (to. face) 30

IV Racioactivity excreted in urine...(to. face). 32

$\mathrm{V}$ Total radioactivity excreted in expired $\mathrm{CO}_{2}$ and urine............ face)... 32

VI Specific activities of nucleic acid purines and thymine of growing Novikoff hepatoma............... (to follow)....

VII Radioactivity excreted in urine during growth of radioactive Novikoff hepatoma.............. (to follow).... 


\section{INTRODUCTION}

In studying the nucleic acid metabolism of tumor and non-tumor tissue, it was felt that useful information could be obtained from a comparison of a neoplastic tissue and a rapidly growing non-neoplastic tissue. For purposes of such a study, Novikof $f$ hepatoma and regenerating liver were eminently suitable tissues, since the Novikoff hepatoma is a neoplasm which had been induced in rat liver and established in a transplantable form by Novikoff (1). On the other hand regenerating rat liver provided a rapidly growing non-neoplastic tissue. A comparison of these tissues seemed reasonable in view of their common cell origin. Investigators in the past who have studied the nucleic acid metabolism of tumor and normal tissues have for the most part compared neoplastic and normal tissues which were unrelated in cell origin. Regenerating liver has been extensively used as a source of rapidly growing non-neoplastic tissue and compared to tumors, but again most of the data obtained from studies of the nucleic acid metabolism of this tissue have been related to tumor tissue which did not originate from hepatic tissue.

Therefore the present study was undertaken in order to compare the nucleic acid metabolism of Novikoff hepatoma and regenerating rat liver. Fur thermore the presence of these two tissues in vivo provided an opportunity to study the effect of Novikoff hepatoma and regenerating liver on the nucleic acid metabolism of other tissues of animals containing one or both 
of the above rapidly growing tissues, as well as the effect of the hepatoma and regenerating liver on each other.

I. Studies Comparing Tumor and Non-tumor Tissues.

Studies on the utilization of several nucleic acid precursors by malignant and benign tumors as compared to non-tumor tissues have been carried out by several investigators. Brues, Tracy and Cohn (2) demonstrated that the rate of uptake of $\mathrm{p}^{32}$ by the nucleic acids of a hepatoma was intermediate between that of resting and regenerating Iiver. On the other hand LePage and Heidelberger (3) found the incorporation of glycine-2-C 14 was small in the thymus of rats, greater in the normal liver, and greatest in regenerating liver and Flexner-Jobling carcinoma. Subsequent experiments $(4-7)$ have al so demonstrated a greater incorporation of glycine-2-C $\mathrm{C}^{14}$ and $\mathrm{p}^{32}$ into tumor tissue as compared to non-tumor tissue. Recently Reddy and coworkers (8) have found a higher incorporation in vitro of $\mathrm{p}^{32}$ into the ribonucleic acid (RNA) of several mal ignant human ovarian tumors as compared to benign human ovarian tumors. A higher incorporation of $p^{32}$ into the deoxyribonucleic acid (DNA) of most of the malignant tumors was also noted, but the differences were of a smaller magnitude. Wells and Winzler (9) have also observed a higher incorporation in vitro of formate-c 14 into the acid-soluble nucleotides of human leukemic cells as compared to normal 
leucocytes, the descending order of specific activity being acute leukemia, chronic granulocytic leukemia, chronic lymphocytic leukemia and normal leucocytes. Similar findings had been reported by Tuttle and associates (10) who found that leukemic infiltration into the liver, spleen and lymph nodes of mice, was accompanied by an increase in the uptake and retention of radioactive phosphorus by the nucleoproteins and acid-soluble fractions of these tissues.

Investigations of the incorporation of preformed precursors in to the nucleic acids of tumor tissues have also been carried out. Weed and Wilson $(11,12)$ have found a higher incorporation of orotic acid-2-C 14 into thymidylic, uridylic and cytidylic acids of tumor slices as compared to liver slices. In contrast Hurlbert and Potter (13) have obtained a relatively small amount of incorporation in vivo of orotic acid- $6-\mathrm{c}^{14}$ into subcutaneous tumor transplants as compared to liver. The difference in the incorporation was attributed to the greater ability of the liver to absorb and utilize the orotic acid. Using uracil-2-c 14 as a precursor, Rutman and coworkers (14) observed a higher incorporation into the nucleic acids of rat hepatoma as compared to those of nornal liver. Comparable results were obtained by Heidelberger et al. (15) who found that the specific activity of the nucleic acids and acid-soluble nucleotides was higher in a subcutaneous tumor than in normal rat liver 
following the administration of uracil-2-C ${ }^{14}$. The latter authors note that the increased incorporation is not specific to tumor since they found a comparable conversion of uracil into the nucleic acid pyrimidines of intestinal mucosa of normal rats. Other authors (16) had previously reported that there was no difference in the rate of incorporation of adenine into the nucleic acids of normal and tumor tissues.

II. The Effects of Tumor on Host Tissues. The effect of tumors on the nucleic acid metabolism of several tissues of the host has been demonstrated for several tumors. Cerecedo et al (17-21) have shown an increase in concentration of nucleic acids in the liver, lungs, kidney, thymus, and lymph nodes of sarcoma-bearing mice; and in the liver, kidneys, and lungs of 12 to 20 day gestational mice (22). This effect was not observed in rats containing regenerating liver (23); and rats containing Walker carcinoma showed a drop in nucleic acid concentration of the thymus and the RNA of the lymph nodes, with an increase in the nucleic acid concentration of the spleen and the RNA of bone marrow (24).

Kelly and associates (25-27) have shown an increased rate of incorporation of $\mathrm{p}^{32}$ into the DNA of livers and spleens of mice and rats bearing several transplanted tumors and in pregnant mice and rats. Similar 
increases in the incorporation of glycine-a-c ${ }^{14}$ and formate-C ${ }^{14}$ into the DNA of host tissues of tumorbearing mice have been reported (28), al though LePage and Heidelberger (3) obtained no significant difference between the incorporation of glycine-2-C ${ }^{14}$ into the DNA and RNA of the liver of rats bearing Flexner-Jobling carcinoma as compared to normal livers. In contrast, it has been demonstrated (5) that the livers of rats bearing Flexner-Jobling carcinoma have a higher uptake of $\mathrm{P}^{32}$ into the DNA nucleotides as compared to normal livers. 0thers $(29,30)$ have observed a similar effect in tumor-bearing mice, in which there was a stimulation

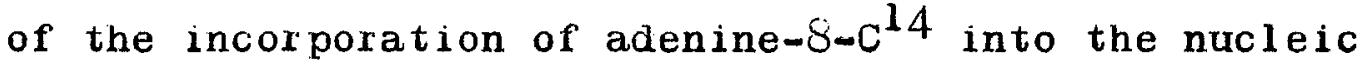
acids of the host tissues. Preliminary studies (30) using in vitro techniques, indicated a stimulation, by tumor tissue, of the incorporation of adenine in to the DNA of normal or gans. In addition, Bal is and coworkers $(31,32)$ reported an increased incorporation of guanine and hypo $x a n t h i n e$ into the RNA of certain host tissues of rats bearing transplanted human tumor. Fur ther to these observations on the effect of tumor on the incorporation of nucleic acid precursors into host tissues, Annau and coworkers (33) and Malmgren (34) have reported an increased mitotic rate in the livers of tumor-bearing mice and rats. 


\section{Studies of Regenerating Liver.}

The early literature pertaining to regenerating liver has been reviewed by Fishback (35). Higgins and Anderson (36) made a careful study of the restoration of the liver in the white rat and observed that after the removal of approximately $70 \%$ of the liver, the remnant more than doubles in size in the course of the following 72 hours. These studies were extended by Brues et al (37) who found that the remnant of liver increased in size between 50 and $60 \%$ during the first 24 hours postoperatively, but observed no increase in the number of hepatic cells during this period. This phenomenon was attributed to an increase in size of the hepatic cells and was followed on the second day by a marked increase in cell division which diminished from then on (37).

By using the early stages of liver regeneration in rats and other animals subjected to partial hepatectomy it was possible to investigate certain processes that occurred in a rapidly growing tissue. In particular, regenerating liver has been widely used in studying nucleic acid metabolism. Since the initial study by Brues et ál (38), numerous investigations have been reported on the incorporation of precursors into the nucleic acids of regenerating Iiver (39-53). Johnson and Albert (41) observed a rapid uptake of $\mathrm{P}^{32}$ into the RNA and DNA of regenerating rat liver during the first 24 hours after operation, followed by a subsequent decline which was accompanied by a marked 
increase in mitosis. This was in general agreement with the results of Price and Laird (54) who found that on a per cell basis, the amounts of nucleic acid, with the exception of nuclear RNA, reached their maximum value before an increase in the number of dividing cells could be detected. Others have reported maximum rates of DNA synthesis in regenerating rat 1 iver at 24 (44) and 24 to 30 (47) hours after hepatectoniy, but after the onset of active mitosis the rate of DNA synthesis tends to fall to a lower level (44). Similar observations have been obtained using partially hepatectomized mice $(45,52)$, and mice on which liver regeneration was induced by the administration of carbon tetrachloride $(50)$.

Using glycine-N $\mathrm{N}^{15}$ as the isotopic precursor, Eliasson et al (40) found maximum incorporation into the purines of the nucleic acids of regenerating rat liver at about 30 hours after partial hepatectomy, but in contrast to the aforementioned results, Eliasson et al observed that the maximum rate of polynucleotide synthesis coincided in time with the maximum of mitosis frequency. In more recent papers $(55-57)$ the latter investigators found an initial peak of glycine incorporation into the FNA purines at 14 hours after operation. However this initial high peak did not coincide with the maximum rate of synthesis of RNA, and apparently represented some turnover process distinct from net synthesis of new mole- 
cules. A smaller broader peak of glycine uptake into RNA occurred around 26 to 56 hours postoperatively, and was found to correlate with the maximum rate of RNA synthesis. The major peak of incorporation into DNA occurred at 26 - 32 hours and coincided with the peak of mitosis frequency and to a large extent with the time of maximum DNA synthesis.

\section{Metabolic Interrelations of Regenerating} Liver and Tumor Tissues.

A number of workers have reported results of experiments in which the nucleic acid metabolism of tumor was studied in animals containing regenerating liver. At the same time the effect of tumor on regenerating liver has been noted, as well as the effect of the combination of these two tissues on other host tissues. Experiments of this type have been reported by LePage and Heidelberger (3) using partially hepatectomized rats bearing subcutaneous implants of Flexner-Jobling carcinoma. Their results indicated that the presence of tumor and regenerating liver in one animal had no effect on the incorporation of glycine-2-c 44 into regenerating liver or tumor as compared to animals containing either regenerating liver or tumor. They provided no data for other tissues of the animal. Paschkis et al (58) observed that in the presence of regenerating liver, the growth of two tumors of epithelial origin was accelerated, but no acceleration was noted in two sarcomatous tumors under 
similar conditions. Liver regeneration was enhanced in the presence of a growing tumor regardless of whether the growth of the latter was influenced by the liver regeneration. The latter authors postulated the release of a "growth promoting agent" from the regenerating liver into the circulation which was selective in its effect on "target" tumors. In agreement with this hypothesis was the work of Bucher and coworkers (59) and Wennecker and Sussman (60) who have reported that partial hepatectomy of one member of a parabiotic pair causes increased weight and mitotic activity of the liver of the other intact parabiont. The nature of the "growth promoting agent" is unknown as is the mechanism underlying the enhancement of liver regeneration in the presence of a growing tumor (58). In addition Bal is and associates (61) have observed a greatly increased uptake of adenine, 2, 6 diaminopurine, hypoxanthine, and glycine into the purines of tissues of hamsters containing regenerating liver, as compared to controls. The same authors have also reported (61) that a human sarcoma transplanted into hamsters was affected by the presence of regenerating liver in the sarcoma-bearing animals. Using 2, 6 diaminopur ine, guanine or hypoxanthine as precursor, there was no appreciable change in the uptake by the tumor of the administered purine, but when adenine was given, there was a three fold increase in the uptake of this precursor by the tumor. The utilization of glycine by the tumor, on the other hand, was reduced. There were 
no striking changes noted in the incorporation of the precursors into the host's tissues of the partially hepatectomized-tumor-bearing hamsters.

\section{The Present Investigation.}

The experiments to be described were undertaken in order to compare the metabolism of the nucleic acids in Novikoff hepatoma and regenerating rat 1 iver and to determine any possible effects of one or both of these tissues on the nucleic acid metabolism of the tissues of the host.

The maximum mitotic activity was used as an index of the maximum rate of growth of the hepatoma and regenerating liver. Therefore rats containing about 40 hour postoperative regenerating rat 1 iver were used since this approximated the period of maximum mitotic frequency (36, $37,40,41,54,55)$. The mitotic index of the Novikof $f$ hepatoma was determined on successive days after transplantation and found to be maximal during the fourth day of intraperitoneal growth. In most cases rats containing 40 hour regenerating liver and fourth day tumor were used to compare the incorporation of sodium formate- $\mathrm{C}^{14}$ into the nucleic acid purines and pyrimidines of these tissues. Formate was used as a measure of the de novo biosynthesis of nucleic acid since it is incorporated into positions 2 and 8 of the purine $\mathrm{ring}$ via the formate donor $\mathrm{N}^{10}$-formyl tetrahydro folic acid $(62,63)$, and into the methyl group of thymine. In vivo experiments were performed throughout and in order to increase the significance of the findings, 
groups of 2 to 4 rats were used in each experiment and the tissues pooled.

The results to be described in this thesis demonstrated a greater incorporation of formate-C $\mathrm{C}^{14}$ into the nucleic acid of regenerating liver as compared to normal liver. As well, a higher formate incorporation into the nucleic acid of the hepatoma was observed, as compared to regenerating liver. In contrast to the results of others, in which partially hepatectomized-tumorbearing animals were studied, the results described herein indicated that the presence of regenerating 1 iver and Novikoff hepatoma in the same rat had no significant effect on the incorporation of formate into the nucleic acid bases of intestinal mucosa, spleen, regenerating liver or tumor, as compared to the appropriate control. These results were interpreted as an indication of the autonomy of tumor and regenerating 1 iver, since the presence of these two rapidly growing tissues in one animal, did not affect their ability to incorporate formate into their nucleic acids. These findings were even more striking in view of the results which showed that the available radioactive formate was rapidly depleted soon after administration as a result of the rapid and extensive excretion of radio activity in the expired $\mathrm{CO}_{2}$ and urine. 
Therefore it was of interest to determine the incorporation of formate into the regenerating liver of tumor-bearing animals which had been injected with formate-C ${ }^{14}$ prior to the partial hepatectomy. The results of this experiment indicated that there was little difference in the formate incorporation into the nucleic acids of the regenerating livers of these animals than into the nucleic acids of the livers of the tumorbearing control animals. Furthermore the extent of formate uptake into the tumor and host tissues was similar in the two sets of animals.

A preliminary experiment was performed to determine the distribution of radioactivity in animals which had been injected with a radioactive suspension of Novikoff hepatoma. It was hoped that such an experiment would also provide an opportunity to study the nucleic acid metabolism of the growing Novikoff hepatoma. Al though many of the results of this experiment were not significant, it was evident that approximately 20 per cent, of the radioactivity administered in the tumor suspension, was excreted in the urine during the first 24 hours of tumor growth.

The results of the experiments which have 
been described are not completely in accord with the findings of others. The significance of these apparent differences has been discussed. 


\section{EXPER IMENTAL}

A. METHODS

\section{Materials.}

Male Sprague-Dawley rats (180-200 grams) from the colony at the University of British Columbia, were used in all experiments. The animals were fed Buckerfield's Vita-Gras Pellets ad libitum.

The Novikoff hepatoma has been maintained, in the Department of Biochemistry, University of British Columbia, by weekly intraperitoneal transplantion of 0.3 or 0.4 ml. of a 1 in 5 dilution of a minced tumor cell suspension in physiological saline. For the experiments described herein, $0.5 \mathrm{ml}$. of the tumor cell suspension was transplanted into each rat in order to obtain a larges: mass of tumor .

Sodium formate-C 14 was obtained from Atomic Energy of Canada and from Merck and Company Limited. For injection it was dissolved in $5 \mathrm{ml}$. of slightly alkaline water.

II. Partial Hepatectomies.

The partial hepatectomies were performed under ether anesthesia, using essentially the same method as described by Higgins and Anderson (36). No precautions were taken to

I Manufactured by Buckerfield's Limited, Vancouver, British Col umbia. 
obtain a sterile technique, al though cleanliness was observed during the procedure. The left lateral lobe was 1 igated at the pedicle using 00 black silk suture and excised. The middle lobe was then excised in a similar manner. The abdomen was closed in one layer using 000 or 00 black silk continuous sutures. The animals were maintained on their usual diet before and after operation. A low postoperative mortality was obtained.

Renoval of the left lateral and median lobes of the rat liver represents a loss of approximately $70 \%$ (36) of the intact liver. The normal livers, of the animals used, had a wet weight of 6.5 to 8.5 grams. Therefore the remnant remaining after partial hepatectomy was calculated to weigh 2.0 to 2.5 grams. After 40 hours of regeneration the 1 iver remnant weighed 3.0 to 4.5 grams, indicating an increment in 1 iver weight of 1 to 2 grams during this period of restoration. The wet weight of fourth day tumor was approximately 1.5 to 2.5 grams. There was no significant difference, from these values, in the weight of regenerating liver or tumor in the partially hepatectomized-tumor bearing animals.

\section{Mitotic Counts.}

In comparing the incorporation of formate- $\mathrm{C}^{14}$ into the nucleic acids of Novikof hepatoma: and regenerating rat 1 iver, it was felt that the determination of formate incorporation into each tissue should be made at the time of 
maximal rate of growth of each tissue. In this way the nucleic acid metabolism of each tissue could be studied under comparable conditions of growth. The period of maximum mitotic frequency was used as an index of the maximum rate of growth of each tissue.

As previously stated, information obtained from the literature indicated that the period of maximum mitotic frequency of regenerating liver occurred approximately 40 hours after the partial hepatectomy. In order to determine the period of maximum mitosis of the Novikoff hepatoma, mitotic indices of the tumor were determined at daily intervals after transplantation. After histological preparation, the nuclei of individual fields were counted under the microscope, and the percentage of nuclei undergoing mitosis was determined. Preliminary mitotic counts were difficult and inaccurate, because of difficulty in identifying the various stages of mitosis. This problem was overcome by injecting colchicine prior to removing the tumor tissue, as described by Leblond and Walker (64). Each tumor-bearing rat was injected subcutaneously with colchicine (0.1 milligram per 100 grams body weight) 6 hours prior to killing the animals. In this way, cell nuclei undergoing mitosis vere stopped at the metaphase stage. This phase of mitosis was readily identified, and made for a faster and more accurate determination of the mitotic activity.

Portions of the solid hepatoma, from the periphery of the tumor mass, were obtained at daily intervals after 
transplantation from separate tumor-bearing rats. The tissues were prepared for mitotic counts using two techniques.

1. "Standard" Technique. The fresh tumor tissue was fixed in formalin, stained with hematoxylin and eosin, and sectioned using a microtome. Staining and sectioning of the tissue was performed by members of the Department of Pathology, University of British Columbia. Different fields were counted under oil immersion until a total of 500 nuclei had been counted for each tumor.

2. "Squash" Technique. A small portion of the fresh tumor was squashed on a microscope slide to disperse the tissue into a layer one cell in thickness. The "squash" was then stained with aceto-carmine. Aceto-carmine is a dye which preferentially stains chromosomes, and therefore is advantageous in the determination of mitotic counts. Different fields were counted under oil immersion until a total of 1,000 nuclei had been counted for each tumor.

IV. Collection of Expired $\mathrm{CO}_{2}$.

In those experiments in which the radio activity of the expired $\mathrm{CO}_{2}$ was determined, the procedure as described by Zbarsky and Wright (65) was used. The animals were placed in a sealed metabolism cage through which carbon dioxide-free air was passed. The expired $\mathrm{CO}_{2}$ was 'bubbled' through carbonate-free 5,10 or $15 \% \mathrm{NaOH}$, depending on the period of time during which the $\mathrm{CO}_{2}$ was collected. The alkaline solution containing the expired $\mathrm{CO}_{2}$ was quantitatively collected, and 
made to volume with $\mathrm{CO}_{2}$-free water. Appropriate al iquots were removed (if necessary non-isotopic $\mathrm{Na}_{2} \mathrm{CO}_{3}$ was added as carrier), and the carbonate precipitated as $\mathrm{BaCO}_{3} \cdot$

v. Collection of Urine.

Urine specimens were collected in all experiments in which formate- $\mathrm{C}^{14}$ was administered. In those experiments in which the expired $\mathrm{CO}_{2}$ was collected, the urine was collected at $3,6,12,24,36,48$ etc. hours after the injection of the radioactive formate. In all other experiments the urine was collected at 12 hour intervals. Toluene or mercuric chloriảe was added as preservative.

VI. Isolation of Purines and Pryimidines.

The animals were killed by exsanguination under the anesthesia and the tissues quickly removed and frozen. The various tissues from the group of animals were pooled, and the 1 ipids extracted by homogenizing in $95 \%$ ethanol, ethanol-ether $(3: 1)$ and ether. The fat-free tissues were dried and the sodium nucleates extracted by continual stirring in $10 \% \mathrm{NaCl}\left(20 \mathrm{ml}\right.$. per 0.6 gram dry weight) at $85^{\circ} \mathrm{C}$ for 6 hours. The sodium nucleates were precipitated by the addition of 3 volumes of $95 \%$ ethanol and chilled overnight. The precipitated sodium nucleates were extracted with 10 volumes of $5 \% \mathrm{NaCl}$ by stirring at $85^{\circ} \mathrm{C}$ for 15 minutes, and reprecipitated with 3 volumes of 95\% ethanol and chilled for 2 to 3 hours. The sodium nucleates were collected by centrifugation, washed with ethanol, and ether, and dried. For tissues with a wet 
weight of less than 1 gram, the nucleic acids were extracted according to the method of Hecht and Potter (47). RNA and DNA were separated by the procedure of Tyner, Heidelberger and LePage (5). The DNA and ribonucleotides were then hydrolysed with perchloric acid as described by Marshak and Vogel (66). The hydrolysate was neutralized by the addition of $50 \%$ potassium hydroxide, chilled, and the precipitated potassium perchlorate removed by centrifugation. The purines and pyrimidines, contained in the super natant, were separated by ion exchange chromatography on columns of Dowex-50 (200 - 400 mesh ), H form. In most instances columns measuring $1 \times 15 \mathrm{~cm}$. were used, however for smaller quantities, the columns were reduced to $1 \times 8 \mathrm{~cm}$. Distilled water was used as eluent for the first 20 to $30 \mathrm{ml}$., followed by $1.5 \mathrm{~N} \mathrm{HCl}$. The eluate was collected in fractions of 2 to $3 \mathrm{ml}$. using a Technicon Timeflow Fraction Collector. VII. Ultraviolet Spectrophotometry.

The optical densities, at 260 millimicrons, of the fractions from the ion exchange columns were determined using a Beckman DU spectrophotometer. The fractions containing the individual pyrimidines and purines were pooled, evaporated to dryness, dissolved in $0.1 \mathrm{NH} \mathrm{Cl}$ and made up to volume. The absorption spectrum of each base was determined using a Beckman DK-2 ratio recording spectrophotometer, and the concentrations determined from the following molar extinction coefficients ${ }^{2}$ : 


$$
\begin{aligned}
& \text { uracil }-7.56 \times 10^{3} \text { at } 257.5 \mathrm{mill} \text { imicrons, } \\
& \text { thymine }-7.91 \times 10^{3} \text { at } 263.5 \mathrm{mil} 1 \mathrm{imicrons}, \\
& \text { cytosine- } 10.36 \times 10^{3} \text { at } 274.5 \mathrm{mill} \text { imicrons, } \\
& \text { guanine }-11.42 \times 10^{3} \text { at } 248 \text { millimicrons, } \\
& \text { adenine }-13.50 \times 10^{3} \text { at } 261.5 \mathrm{millimicrons} .
\end{aligned}
$$

\section{Radioactive Counting Procedures.}

All radioactive counting was done in a window

less gas flow counter. Suitable aliquots of the purine and pyrimidine solutions were counted on aluminum planchets covered with lens paper. Specific activities of the purines and pyrimidines were expressed as counts per minute per inicromole (c.p.m. / $\mathrm{MM}$ ) and the results for each experiment compared in terms of relative specific activity (R.S.A.) equal to:

$$
\frac{\text { specific activity of purine or pyrimidine }(c \cdot p \cdot m \cdot / \mu M)}{\text { specific activity of injected formate }(c \cdot p \cdot m \cdot / \mu M)} \times 10^{5}
$$

Barium carbonate samples were counted as "infinitely thick" samples. The minimum weight of barium carbonate required to produce an "infinitely thick" sample was found to be $120.0 \mathrm{mg}$. for the particular assembly used (67). In order to correct to thin samples the counts were multiplied by a factor of 4.33 . This factor was determined by oxidizing a suitable aliquot of formate-C $\mathrm{C}^{14}$ to $\mathrm{C}^{14} \mathrm{O}_{2}$, which was precipitated as $\mathrm{BaC}^{1} 4_{0_{3}}$. The latter was counted and the amount of self absorption determined by reference to a thin sample count of the formate-C ${ }^{14}(67)$. 
In order to prevent the loss of volatile radioactive acidic material, each urine collection was made alkaline. The sample was made up to volume with alkaline water and the radioactivity determined by drying aliquots on aluminum planchets. No correction was made for self absorption. 
B. RESULTS.

I. Mitotic Counts.

On examining the slides prepared by the "squash" technique it was found that the tumor nuclei could be easily detected and counted, since there was adequate dispersion of the tumor cells. Furthermore the fields did. not contain tumor cells in which the nuclei were absent. On the other hand, slides prepared by the "standard" technique, were difficult to examine because most fields were more than one cell in thickness, the cells were crowded together, and many cells were cut by the microtome so as to exclude their nuclei. Therefore it was decided that the "squash" method gave more accurate mitotic counts than the "standard" technique.

An estimation of the mitotic activity of tumor growing during the 1 st and 2nd days after transplantation was not possible because insufficient tumor tissue was obtainable at these times. The mitotic index of 7 th day tumor was also not determined because by this time many of the animals have died as a result of the tumor; and moreover the tumor obtained from those animals which do survive is too necrotic and hemorrhagic to permit the determination of the mitotic index.

From the results of the mitotic counts (Table I) it is evident that Novikoff hepatoma is most active mitotically during the 4 th day of intraperitoneal growth. During the following two days of growth, the mitotic frequency de- 
creases, and on the 6 th day only about $1 \%$ of the nuclei are in mitosis.

\section{TABLE I}

Mitotic indices of Novikoff Hepatoma, as percent of total nuclei in metaphase.

\begin{tabular}{|c|c|c|}
\hline $\begin{array}{l}\text { Day after } \\
\text { trans- } \\
\text { plantation }\end{array}$ & $\begin{array}{l}\text { Percent of total Nuc } \\
\text { "Squashi technique } \\
(1000 \text { nuclei counted) }\end{array}$ & $\begin{array}{l}\text { ei in Metaphase } \\
\text { "Standard" Technique } \\
\text { (500 nuclei counted) }\end{array}$ \\
\hline $3 \mathrm{rd}$ & 10 & 16 \\
\hline 4 th & 10 & 23 \\
\hline 5 th & 6 & 8 \\
\hline $6 \mathrm{th}$ & 1 & - \\
\hline
\end{tabular}

Al though the mitotic index of 3 rd day tumor was similar to that obtained for 4 th day tumor using the "squash" technique, 4th day tumor was preferred because of the larger mass of tumor on that day and also because of the possibility that the mitotic index might be higher than 3rd day tumor in view of the results obtained from the "standard" technique counts. Therefore animals with 4 th day tumor were used in subsequent experiments to compare the incorporation of formate-C $\mathrm{C}^{14}$ into regenerating rat liver and Novikoff hepatoma.

II. Formate Incorporation into the Nucleic Acids of 'I'issues of Partially Hepatectomized and Tumor-bear ing Rats.

In all experiments the solution of sodium formate-C 14 
was injected subcataneously into the dorsum of each rat. The quantities of formate-c ${ }^{14}$ injected into each animal, in the experiments to be described, are shown in Table II. This table also summarizes the time relationship of liver regeneration, tumor growth, and formate-c ${ }^{14}$ injection, as well as showing the number of animals used as a group for each experiment. Data for the 6 th day tumor-bearing rats were obtained by Zbarsky et al (68). The data shown for these animals represent the average of results obtained from two or three single animal experiments.

The specific activities for uracil and cytosine were determined in all experiments, and in most cases were found to be negligible. In some instances the incorporation of formate-c ${ }^{14}$ into uracil and cytosine was significant, but was always considerably less than the incorporation into adenine and guanine, and generally less than thymine. Therefore only the data for thymine, adenine and guanine are presented. The specific activity of DNA adenine and guanine was higher than thymine in all tissues. However the difference in specific activity between the DNA purines and thymine was not constant and varied from one tissue to another. It was also noted in duplicate experiments, that this difference was not constant for a single $t$ issue.

Figures 1 - 4 illustrate the relative specific activities of adenine and guanine obtained from the DNA and RNA of liver, tumor, spleen and intestinal mucosa of 
TABLE II

Time relationship of liver regeneration, tumor growth, and formate-Cl4 incorporation at time rats were sacrificed.

Number of rats in each group. Quantities of formate and $\mathrm{c}^{14}$

\begin{tabular}{|c|c|c|c|c|c|c|}
\hline $\begin{array}{c}\text { Description of } \\
\text { animals }\end{array}$ & $\begin{array}{l}\text { Hours } \\
\text { of } \\
\text { liver } \\
\text { in jec- } \\
t \text { ion }\end{array}$ & $\begin{array}{l}\text { Day of } \\
\text { tumor } \\
\text { growth }\end{array}$ & $\begin{array}{l}\text { Number } \\
\text { of } \\
\text { rats } \\
\text { in } \\
\text { group }\end{array}$ & $\begin{array}{l}\text { C.p.m. of } \\
\text { C } 14 \text { in jec- } \\
\text { ied into } \\
\text { each } \\
\text { rat }\end{array}$ & $\begin{array}{l}\text { Mg of } \\
\text { formate } \\
\text { injected } \\
\text { into } \\
\text { each rat }\end{array}$ & $\begin{array}{l}\text { Period } \\
\text { of for- } \\
\text { mate-C } 4 \\
\text { incor- } \\
\text { poration } \\
\text { in hours }\end{array}$ \\
\hline $\begin{array}{l}\text { 1. Pariialiy } \\
\text { hepa tec- } \\
\text { tomized }\end{array}$ & 40 & - & 3 & $3.72 \times 10^{7}$ & 0.85 & 24 \\
\hline \multirow{2}{*}{$\begin{array}{l}\text { 2. I'umor- } \\
\text { bear ing }\end{array}$} & $=$ & 4 th & 3 & $3.33 \times 10^{7}$ & 1.02 & 24 \\
\hline & $*-$ & $6 \mathrm{th}$ & $\begin{array}{l}2-3 \\
(\operatorname{sing} 1 \mathrm{e})\end{array}$ & $7.50 \times 107$ & 1.03 & 24 \\
\hline \multirow{2}{*}{$\begin{array}{l}\text { 3. Partially } \\
\text { hepatec- } \\
\text { tomized- } \\
\text { tumor- } \\
\text { bearing }\end{array}$} & 40 & $4 t h$ & $\tau=-\infty=2$ & $3.33 \times 10^{7}$ & 1.02 & 24 \\
\hline & 40 & $4 \mathrm{th}$ & 2 & $4.02 \times 10^{7}$ & 1.02 & 24 \\
\hline $\begin{array}{l}\text { 4. Tumor- } \\
\text { bear ing } \\
\text { delayed } \\
\text { he pa tec- } \\
\text { tomy }\end{array}$ & 40 & $6 \mathrm{th}$ & 4 & $3.96 \times 10^{7}$ & 1.02 & 72 \\
\hline \multirow{2}{*}{$\begin{array}{l}\text { 5. Tuinor- } \\
\text { bear ing } \\
\text { contiol } \\
\text { for } 4 .\end{array}$} & $=$ & $6 \mathrm{th}$ & 4 & $3.26 \times 10^{7}$ & 1.02 & 72 \\
\hline & $=$ & $6 \mathrm{th}$ & 3 & $5.96 \times 10^{7}$ & 1.02 & 72 \\
\hline 6. Normal", & - & - & $\begin{array}{l}2-3 \\
(\operatorname{single})\end{array}$ & $7.50 \times 107$ & 1.03 & 24 \\
\hline
\end{tabular}

* Data of Zbarsky et al (68). 
To tace rage 25 .

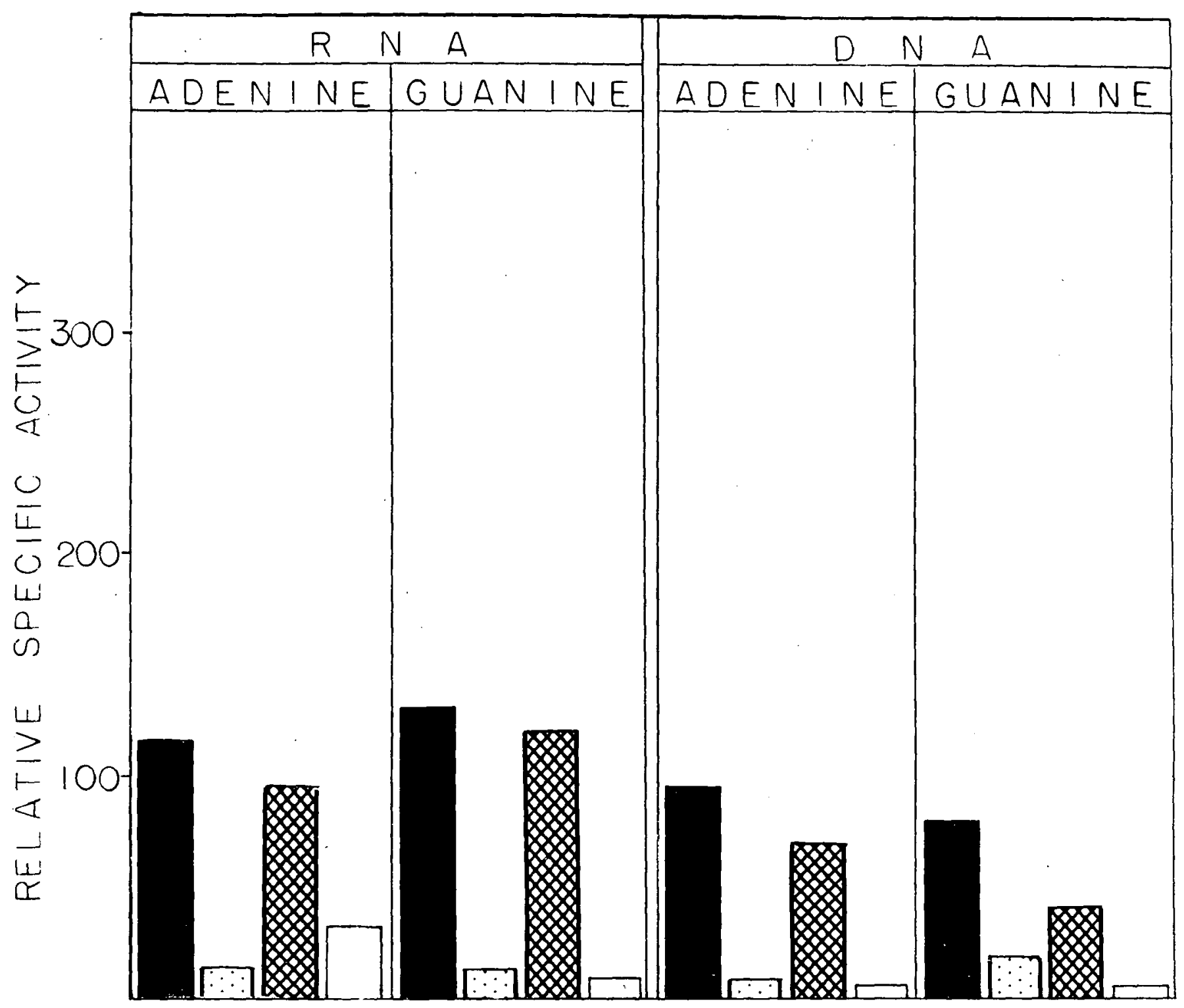

Partially hepatectomized.

$\therefore \quad$ Fourth day tumor-bearing.

Partially hepatectomized-tumor-bearing.

Normal

Figure 1. Relative specific activities of nucleic acid purines of liver from partially hepatectomized, tumor-bearing, partialiy hepatectomized-tumora bearing, and normal rats; 24 hours after the injection of formate-cl4. 
partially hepatectomized, tumor-bearing, partially hepatectomized-tumor-bear ing, and normal rats. The relative specific activities of the DNA thymine from these tissues are illustrated in Figure 5 .

(i) Partially hepatectomized rats. In order to determine the incorporation of formate- $C^{14}$ into the nucleic acids of regenerating rat liver, each of three rats was partially hepatectomized (36), and injected with formate-C $\mathrm{C}^{14} 16$ hours after the operation. Twentyfour hours after the formate injection the animals were sacrificed. The nucleic acid purines and pyrimidines from the regenerating liver, spleen, and intestinal mucosa were analysed for radio activity as described. The results obtained for the purines and thymine of 40 hour regenerating liver alle shown in Figures 1 and 5 respectively. On comparing the relative specific activities of the nucleic acid adenine, guanine and thyinine of the regenerating liver with the corresponding nucleic acid fractions of normal liver, it is evident that the nucleic acids of the former tissue incorporate formate-C ${ }^{14}$ to a much greater degree than those of normal liver. The difference is most apparent on comparing the purine data.

Examination of the data obtained for splean and intestinal mucosa (Figures $3-5$ ) indicates that the presence of 40 hour regenerating rat liver has no effect on the incorporation of formate- $\mathrm{C}^{14}$ into the nucleic acid 
ro fáce Page 26 ,

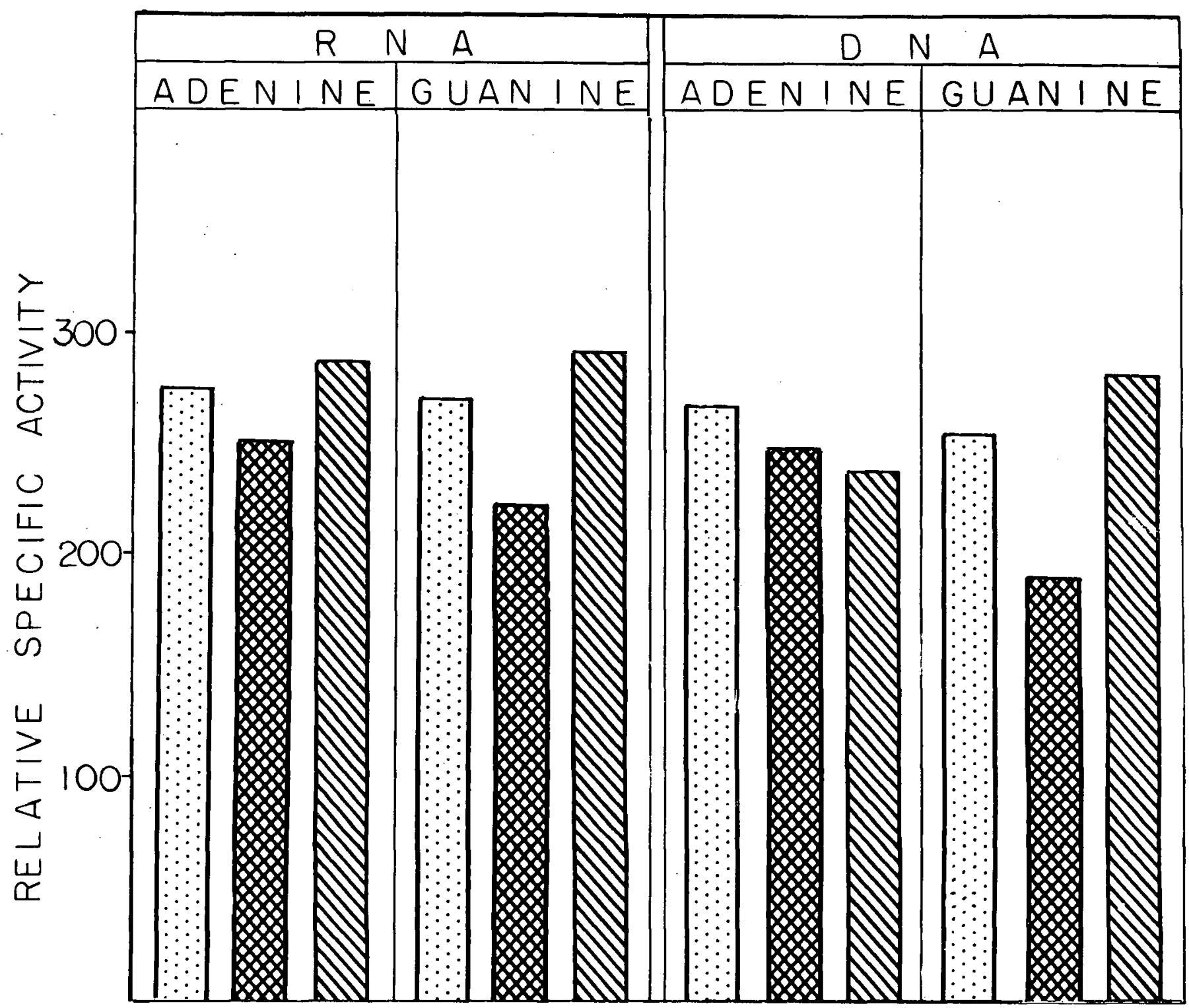

$\because \quad$ Fourth day tumor-bearing.

Partially hepatectomized-tumor-bearing.

MV Sixth day tunor-bearing.

Figure 2. Relative specific activities of nucleic acid purines of Novikoff hepatoma from partially hepatectomized, tumor-bearing, partially hepatectomized-tumor-bearing, and normal rats; 24 hours after the injection of formate-cl 4 . 
purines and thymine of either spleen or intestinal mucosa.

(ii) Tumor-bearing rats. As previously stated, animals bearing 4 th day Novikoff hepatoma were selected for these experiments because of the high mitotic activity observed during the 4 th day of intraperitoneal growth. Three rats were injected intraperitoneally with $0.5 \mathrm{ml}$. of a tumor suspension. At a time during the period 48 to 72 hours after transplantation, each animal was injected subcutaneously with formate-c ${ }^{14}$, and sacrificed 24 hours after the formate injection. Therefore each rat contained 4 th day tumor at the time it wassacrificed.

The results obtained for the relative specific activities of the nucleic acid bases of liver, tumor, spleen and intestinal mucosa are represented in Figures 1 to 5. The data shown for the 4 th day tumor (Figures 2 and 5) indicated a high degree of incorporation of formate-C 14 into the nucleic acid purines and thymine. The extent of incorporation into the tumor is greater than that obtained for regenerating liver and normal spleen, but approximately of the same order as that shown for intestinal mucosa.

It may be noted also that the presence of 4 th day Novikoff hepatoma has little or no influence on the de novo synthesis of the nucleic acids of the host liver, 


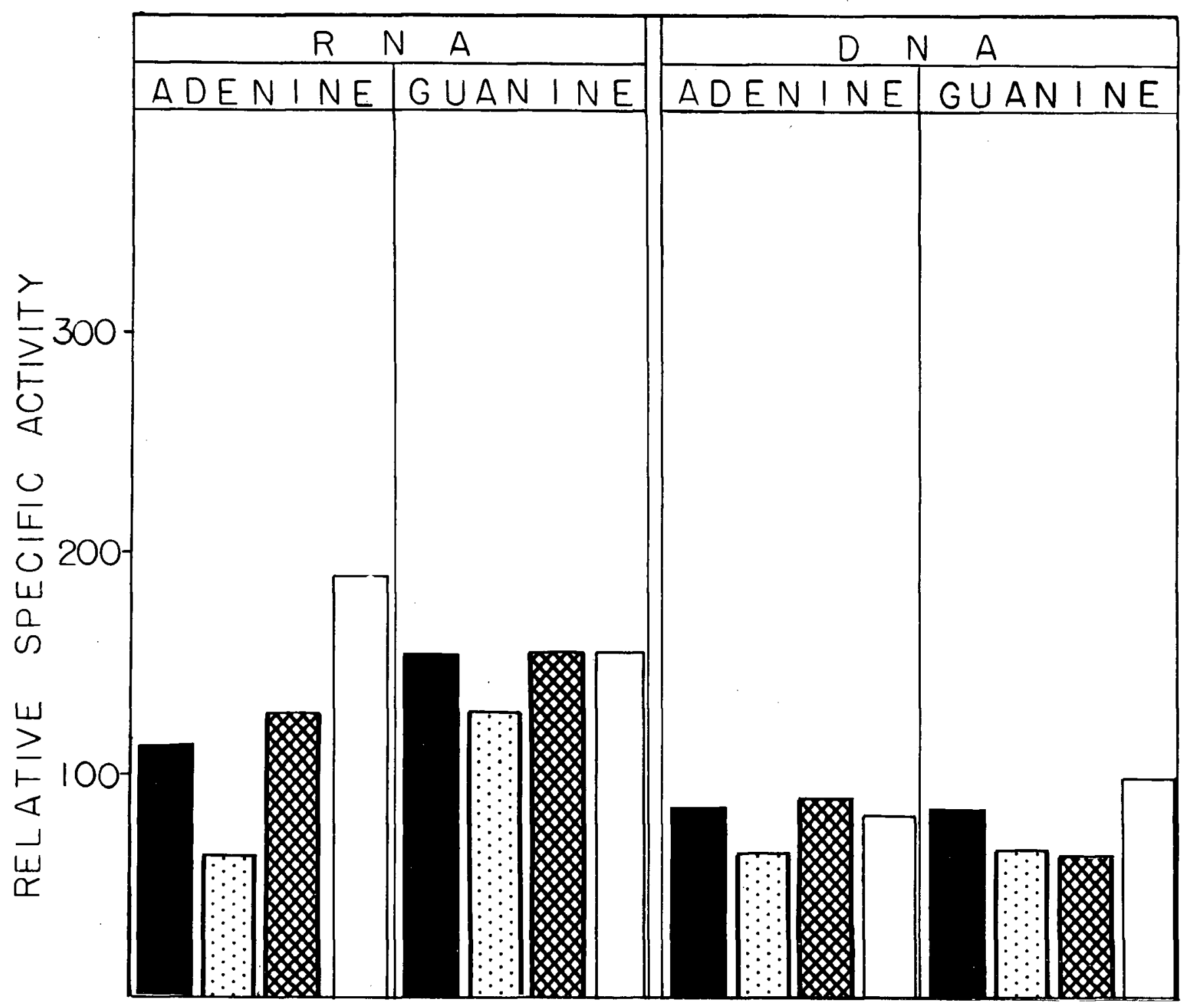

Partially hepatectomized.

$\because \quad$ Four th day tumor-bearing.

Partially hepatectomized-tumor-bearing.

Normal

Figure 3. Relative specific activities of nucleic acid purines of spleen from partially hepatectomized, tumor-bearing, partially hepatectomized-tumorinjection of formate-clis; 24 hours after the 
spleen and intestinal mucosa. In most instances it is seen that the degree of incorporation of formate into the nucleic acid purines and thymine of the host tissues of the tumor-bearing animals is similar to the formate incorporation into the corresponding fraction of the tissues of normal rats. The one exception, as shown in Figure 3 , is the two-thirds decrease in relative specific activity of RNA adenine obtained from the spleens of the $4^{\text {th }}$ day tumor-bearing animals, compared to the RNA adenine of normal spleen.

The data obtained by Zbarsky et al (68) for 6 th day Novikoff hepatoma are presented in Figures 2 and 5. In contrast to the results obtained from mitotic counts of 4 th and 6 th day tumor, which indicated a negligible mitotic activity during the 6 th day of intraperitoneal growth; the data shown indicate no significant difference in the degree of incorporation of formate into the nucleic acids of 4 th and 6 th day tumor.

(iii) Partially hepatectomized-tumor-bearing rats. Since neither regenerating 1 iver or 4 th day Novikoff hepatoma had an effect on the incorporation of formate into the nucleic acids of the host tissues of animals containing either one of the above rapidly growing $t$ issues it was of interest to determine whether the two tissues present in one animal would affect the formate incorporation into the host tissues. At the same time an opportunity would be

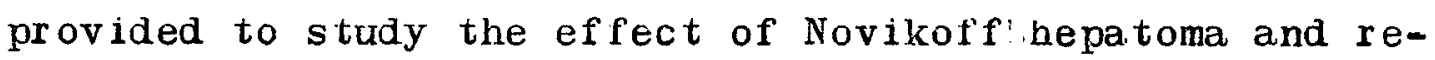


ro follow Page 27.
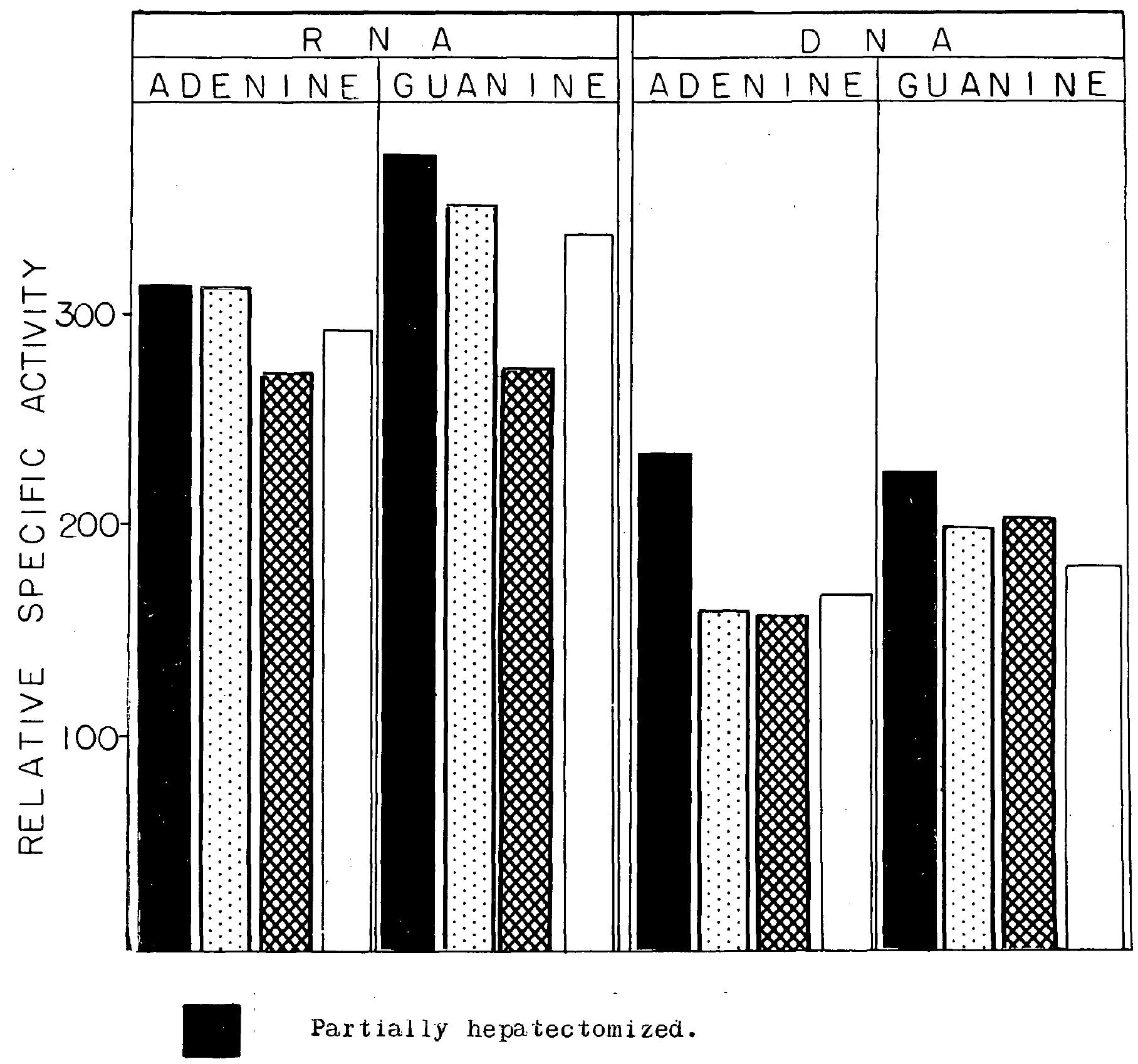

Partially hepatectomized.

$\because \because \quad$ Four th day tumor-bearing.

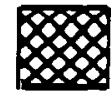

Partially hepatectomized-tumor-bear ing.

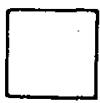

Normal.

Figure 4. Relative specific activities of nucleic acid purines of intestinal mucosa from partially hepatectomized, tumor-bearing, partially hepatectomized-tumor-bearing, and normal rats; 24 hours after the injection of formate-c 4 . 
io face Page $2 \delta$.

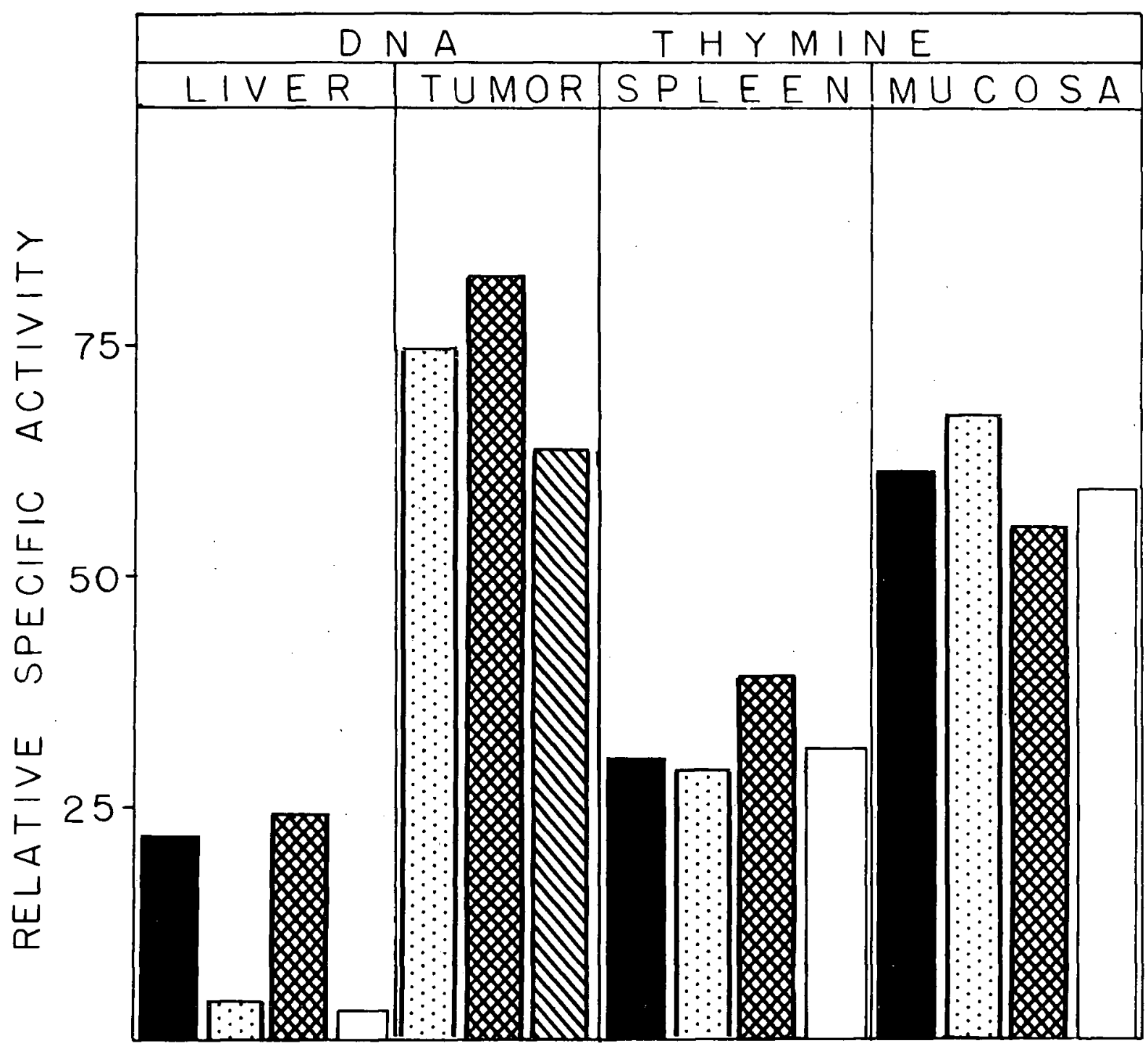

Partialiy hepatectomized.

$\because \quad$ Fourth day tumor-bearing.

Partially hepatectomized-tumor-bearing (4th day). MV Sixth day tumor-bearing.

$\square$ Normal.

Figure 5. Relative specific activities of DNA thymine of liver, Novikof f hepatoma, spleen and intestinal mucosa, from partially hepatectomized, tumorbearing, partially hepatectomized-tumor-bear ing, and normal rats; 24 hours after the injection of 
generating liver on each other.

With these aims in mind, rats containing both regenerating liver and Novikoff hepatoma were prepared. Partial hepatectomies were performed on three tumorbearing rats. The animals were sacr ificed 40 hours later, at which time they contained 40 hour regenerating liver as well as 4 th day Novikoff hepatoma. Similar procedures were carried out on a second group of 2 rats. Formate-c 14 was administered to both groups 24 hours before they were sacrificed. The relative specific activities of the nucleic acid bases of the regenerating livers, tumors, spleens and intestinal mucosa of each group were determined.

The data presented for these experiments in Figures 1 to 5 represent an average of the results obtained from the two groups. From the results shown for partially hepatectomized-tumor-bearing animals it is apparent that the simultaneous presence of the two rapidly growing tissues (regenerating 1 iver and Novikof $f$ hepatoma), in one animal, has no effect on the incorporation of formate-C 14 into the nucleic acids of the host spleen and intestinal mucosa, as compared to the results shown for normal spleen and mucosa. Fur thermore there is no evidence to suggest any effect of regenerating liver on Novikoff hepatoma, or the converse, since there is no significant difference in the formate uptake into the nucleic acids of regenerating liver or Novikof hepatoma in animals con- 
taining these tissues singly or together. It is seen that there is a remarkable similarity in the degree of incorporation of formate into the nucleic acid bases of regenerating liver or Novikoff hepatoma in animals containing one of these tissues as compared to the corresponding functions obtained from animals containing both tissues. These results were even more striking in view of the data obtained for the expired $\mathrm{CO}_{2}$ and urine. This data indicated that the available formate-C ${ }^{14}$ was rapidly depleted as a result of the extensive excretion of radio activity in the $\mathrm{CO}_{2}$ and urine, during the 24 hours immediately following the injection of formate-C ${ }^{14}$ into the partially hepatectomized tumor-bearing animals.

(iv) Excretion of Radio=activity in the Expired $\underline{\mathrm{CO}}_{2}$ and Urine. The expired $\mathrm{CO}_{2}$ was collected from those animals containing 40 hour regenerating 1 iver or 4 th day tumor, as well as from both groups of the partially hepatectomized-tumor-bearing rats. Collections were made at hourly intervals for the first three hours following the administration of the formate and at longer intervals thereafter.

As stated, the $\mathrm{CO}_{2}$ contained in an aliquot of each expired $\mathrm{CO}_{2}$ collection was converted to $\mathrm{BaCO}_{3}$, and the radio activity of the latter determined. The counts were corrected for self absorption and multiplied by 4.33 (see Methods) in order to convert to thin. sample counts. 
To face Page 30.

\section{TABLE III}

Radio activity excreted in expired $\mathrm{CO}_{2}$ during 24 hours immediately following subcutaneous injection of formate-cl4.

\begin{tabular}{|c|c|c|c|c|c|c|c|}
\hline \multirow{3}{*}{$\begin{array}{l}\text { Description } \\
\text { of } \\
\text { Animals }\end{array}$} & \multicolumn{7}{|c|}{ Percent of total Radio activity injected } \\
\hline & \multicolumn{6}{|c|}{ Hours after Formate-C ${ }^{14}$ injection } & \multirow{2}{*}{$\begin{array}{r}24 \text { hour } \\
\text { total } \\
\end{array}$} \\
\hline & $0-1$ & $1-2$ & $2-3$ & $3-6$ & $6-12$ & $12-24$ & \\
\hline $\begin{array}{l}\text { Partially } \\
\text { hepatec- } \\
\text { tomized }\end{array}$ & 29.4 & 10.1 & $3 \cdot 3$ & $3 \cdot 3$ & 2.0 & 1.9 & 50.0 \\
\hline $\begin{array}{l}\text { Sumor- } \\
\text { bearing }\end{array}$ & 29.4 & 8.9 & 2.0 & 1.9 & 1.5 & 1.5 & $45 \cdot 3$ \\
\hline $\begin{array}{l}\text { Partially } \\
\text { hepatec- } \\
\text { tomized } \\
\text { tumora } \\
\text { bearing }\end{array}$ & 16.8 & 12.0 & 2.8 & $3 \cdot 1$ & 2.1 & 1.8 & 38.6 \\
\hline
\end{tabular}


In this way the total radio activity in each collection of expired $\mathrm{CO}_{2}$ was related to the total radio activity administered as formate-c $c^{14}$.

The radio activity determinations for the expired $\mathrm{CO}_{2}$ are shown in Table III. The data represent the radio activity contained in the expired $\mathrm{CO}_{2}$ expressed as the percent of total radio activity injected. Figures given for the partially hepatectomized tumor-bearing animals represent an average of the results obtained from the two groups of animals.

It is evident that a considerable fraction of the administered formate is oxidized to $\mathbb{C O}_{2}$ during. the first hour, after which the radio activity of the expired $\mathrm{CO}_{2}$ decreases. During the 3 rd hour the radio activity in the expired $\mathrm{CO}_{2}$ has decreased to about one-tenth of the initial level, and slowly decreases thereafter.

On totalling the results for the 24 hours of each experiment it is seen that about 40 to $50 \%$ of the injected formate-C $\mathrm{C}^{14}$ was excreted or expired $\mathrm{CO}_{2}$. The difference between the $50 \%$ excreted by the partially hepatectomized animals, and the $38.6 \%$ excreted by the partially hepatectomizedtumor-bearing animals, is probably not significant in view of the small number of experiments performed. Fur thermore these figures are within the range of 40 to $60 \%$ reported by others for normal animals (68).

Urine samples were collected from each group of animals at periodic intervals following the injection of the 
formate-C ${ }^{14}$. Initially the urine was made to volume with distilled water and suitable aliquots plated and dried on aluminum planchetș. On counting these samples it was found that there was not satisfactory agreement between the count of duplicate samples. Since the aliquots of urine had been dried under an infra-red lamp, it was suggested that the discrepancy in the counts might be the result of the evolution of volatile radio active material. Therefore a sample of urine was plated and counted. The same sample was then heated at $100^{\circ} \mathrm{C}$ for about $1 / 2$ hour, and the radio activity again determined. It was found that the counts obtained following heating of the sample was considerably lower than the original count. The $\mathrm{pH}$ of the urine sample was determined and found to be about 5 to 6 . Therefore it was thought that the drop in radio activity after heating of the urine was due to the evolution of volatile radio active acidic material. This was a possible explanation for the lack of agreement in counts of duplicate urine samples. With this in mind, each urine sample was adjusted to about $\mathrm{pH}$ 9 by the addition of sodium carbonate. Aliquots of the alkaline urine were plated, and where necessary, alkal ine water was used to evenly distribute the sample on the planchet. In this way satisfactory agreement was obtained on counting duplicate samples. In all future experiments the urine samples were made alkaline by the addition of $\mathrm{Na}_{2} \mathrm{CO}_{3}$ and then diluted to volume using alkaline water. 
To face Page 32.

\section{TABLE IV}

Radio activity excreted in urine during 24 hours immediately following subcutaneous injection of formate-cl 4 .

\begin{tabular}{|c|c|c|c|c|c|}
\hline \multirow{2}{*}{$\begin{array}{l}\text { Description } \\
\text { of animals }\end{array}$} & \multicolumn{5}{|c|}{ Percent of total radio activity in jected } \\
\hline & \multicolumn{4}{|c|}{\begin{tabular}{|l|l|l|l|} 
Hours after formate-cl4injection \\
$0-3 \mid 3-6$ & $6-12$ & $12-24$
\end{tabular}} & $\begin{array}{l}24 \text { hour } \\
\text { total }\end{array}$ \\
\hline $\begin{array}{c}\text { Partially } \\
\text { hepatec- } \\
\text { tomized }\end{array}$ & 3.7 & $3 \cdot 3$ & 1.1 & 1.6 & $9 \cdot 7$ \\
\hline $\begin{array}{l}\text { Tumor- } \\
\text { bearing }\end{array}$ & 0.9 & 0.8 & 1.0 & 1.1 & 3.8 \\
\hline $\begin{array}{l}\text { Partially } \\
\text { hepatec- } \\
\text { tomized- } \\
\text { tumor } \\
\text { bearing }\end{array}$ & 2.8 & 1.2 & 1.5 & 1,2 & 6.7 \\
\hline
\end{tabular}

\section{TABLE V}

Total radio activity excreted in expired $\mathrm{CO}_{2}$ and urine in 24 hours immediately following subcutaneous injection of formate-cl4.

\begin{tabular}{|c|c|c|c|}
\hline \multirow{2}{*}{$\begin{array}{c}\text { Description } \\
\text { of animals }\end{array}$} & \multicolumn{3}{|c|}{ Percent of total radio activity injected } \\
\cline { 2 - 4 } & $0-24$ hours after formate-Cl4 injection \\
\cline { 2 - 4 } & $\mathrm{CO}_{2}$ & Urine & $\mathrm{CO}_{2}+$ Urine \\
\hline $\begin{array}{c}\text { Partially } \\
\text { hepatec- } \\
\text { tomized }\end{array}$ & 50.0 & 9.7 & 59.7 \\
\hline $\begin{array}{c}\text { Tumor- } \\
\text { bearing }\end{array}$ & 35.3 & 3.8 & 49.1 \\
\hline $\begin{array}{l}\text { Partially } \\
\text { hepatec- } \\
\text { tomized- } \\
\text { tumor- } \\
\text { bearing }\end{array}$ & 6.7 & 45.3 \\
\hline
\end{tabular}


The nature of the volatile radio active acidic material was not determined.

The ur ine counts were not corrected for self absorption and therefore the results shown in lable IV are approximations of the radio activity of each urine sample. The data in Table IV represent the radio activity excreted in the urine, expressed as percentages of the total injected radio acitivity. Considerably less of the injected radio activity is excreted in the urine as compared to that excreted in the expired $\mathrm{CO}_{2}$. There is a suggestion that the excretion of radio activity in the urine is greatest during the initial few hours after the formate injection, however this is not as evident as the data already presented for the expired $\mathrm{CO}_{2}$. There is also some variation, between the several types of animals, in the percent of radio activity excreted in the urine during the total 24 hour period. Again these variations are not significant because of the limited number of experiments performed. As well they do not coincide with the data given for the expired $\mathrm{CO}_{2}$, in which the excretion of radio activity was lowest in the partially hepatectomized-tumor-bear ing animals.

On totalling the results for the expired $\mathrm{CO}_{2}$ and urine (Table V), it will be noted that about 45 to $60 \%$ of the injected radio active formate can be accounted for in the $\mathrm{CO}_{2}$ and urine excreted during the 24 hours immediately following the injection of formate-c 14 . 
(v) Tumor-bear ing Rats Injected with Formate-C ${ }^{14}$

followed by Partial Hepatectomy. The uptake of formate into the nucleic acids of regenerating liver and Novikoff hepatoma inpartially hepatectomized-tumor-bearing animals indicated an autonomy in the nucleic acid metabolism of both regenerating rat 1 iver and Novikoff hepatoma. Each of these tissues together in one animal was able to incorporate formate into their nucleic acids to the same degree as regenerating liver or hepatoma in separate animals. Fur thermore the formate incorporation occurred in spite of the rapid excretion of precursor in the expired $\mathrm{CO}_{2}$ and urine. With these results in mind, an experiment was planned to determine the degree of incorporation of radio activity into regenerating liver in tumor-bearing animals which had been injected with formate$\mathrm{C}^{14}$ prior to the partial hepatectomy.

Each of 4, 3rd day tumor-bearing rats was injected subcutaneously with formate-C ${ }^{14}$. The rats were placed in open metabolism cages and the following day partial hepatectomies were performed on the animals. The rats were killed 40 hours later and the liver, tumor, spleen and intestinal mucosa analysed. Thereforeat the $t$ ime the animals were sacrificed they contained 6 th day hepatoma, 40 hour regenerating 1 iver and had been injected with formate-C ${ }^{14} 72$ hours beforehand. As control animals for this experiment, 2 groups of 3 and 4 rats, containing 3rd day tumor were in jected with formate-C ${ }^{14}$ and sacrificed 72 hours later. 
The results of these experiments are illustrated in Figure 6. The relative specific activities shown for the tumor-bearing control animals represent an average of the values obtained from the two groups. It will be noted that there are no significant differences in the incorporation of formate into the nucleic acid purines and thymine of the regenerating livers as compared to the corresponding fractions of the livers from the tumor-bearing animals. As well data obtained for the Novikoff hepatoma and intestinal mucosa indicate no difference in the formate incorporation into the corresponding nucleic acid bases of these tissues in the two types of animals. However a difference is noted in the kNA guanine of spleen. It is observed that the relative specific activity of the RNA guanine of the spleens of the tumor-bearing animals is slightly greater than that found for the corresponding fraction of the tumor-bearing delayed-hepatectomized animals. It is not possible to compare the RNA adenine fractions of spleen, since in one of the experiments this fraction was lost, although it is seen that the RSA of RNA adenine of the tumor-bearing spleen is relatively high. However there are no significant differences in the formate incorporation into corresponding DNA bases from the spleens of the two sets of animals.

It will be noted that the relative specific activities obtained for the purines and thymine in these 
experiments, in which the formate-c ${ }^{14}$ was injected 72 hours before the animals were killed, are considerably lower than those of corresponding nucleic acid fractions, obtained from animals which were killed 24 hours after the injection of the formate. A further observation that can be made regarding the data is that, with one exception, the incorporation of formate into the nucleic acid purines of intestinal mucosa is generally higher than into the corresponding purines of the other tissues studied. The exception, as already noted, is the relatively high incorporation of formate into the RNA purines of tumorbearing spleen.

III. Transplanted Radio active Novikoff hepatoma.

As previously stated, this experiment was performed in order to study the distribution of radioactivity in animals which had been transplanted with a radio active suspension of the Novikoff hepatoma. Furthermore an experiment of this nature would provide an opportunity to study the nucleic acid metabolism of the Novikoff hepatoma as it grew within the peritoneal cavity of the rat.

The experiment was carried out in the following manner: Each of two 6th day-tumor-bearing rats were injected on two occasions, at an interval of one hour, with $5.3 \times 10^{7} \mathrm{c} \cdot \mathrm{p} . \mathrm{m}$. of $\mathrm{C}^{14}$ in $1.36 \mathrm{mill}$ igrams of formate. 
Ninety minutes after the second injection, the rats were sacrificed, and a tumor cell suspension for transplantation prepared in the usual manner. Eight rats were injected intraperitoneally with $0.5 \mathrm{ml}$. of the suspension and divided into 4 groups of two each. One group was sacrificed each day for the following 4 days and the nucleic acid purines and pyrimidines of the tumors analysed. In some cases the expired $\mathrm{CO}_{2}$ was collected. The urine was collected from each group. Part of the donor tumor suspension was reserved and analysed. Duplicate $0.1 \mathrm{ml}$. portions of the donor suspension were made alkaline, plated and counted. No correction was made for self absorption. From these counts it was calculated that $0.5 \mathrm{ml}$. of tumor suspension contained $55,050 \mathrm{c} \cdot \mathrm{p} \cdot \mathrm{m}$. of $\mathrm{c}^{\mathbf{1 4}}$. Therefore each group of 2 rats received a total dose of 110,100 c.p.m. Duplicate $0.1 \mathrm{ml}$. portions of the same donor suspension were made acid, plated, and counted. No decrease in radio activity was noted as compared to the alkal ine samples. Therefore it was indicated that a negligible amount of the radio activity, detected in the donor suspension, was present as formate. The nucleic acids were extracted from the remaining donor tumor suspension and the specific activities of the purines and pyrimidines determined.

One group of rats was sacrificed on succeeding days after the transplantation, and the tumor tissue 
pooled and analysed. Therefore specimens of tumor were obtained which had been growing intraperitoneally for 24, 48, 72 and 96 hours. The results of this experiment are shown in Table VI.

A relatively high specific activity was obtained for each of the nucleic acid purines and thymine of the donor tumor suspension. However after 24 hours of intraperitoneal growth, the specific activities of the tumor had decreased to negligible amounts, and remained so during the 4 days of tumor growth. In most cases the count obtained for the purines and pyrimidines of the growing tumers were not significant. As previously stated, the amount of tumor present 24 and 48 hours after transplantation is negligible, and it is therefore difficult to detect the growing tumor at these times. It was observed that the tumor mass present 3 days after transplantation was at tached to the greater omentum. Therefore the latter tissue was excised from the one and two day tumor-bearing rats, and examined. In some of these cases, isolated masses of tumor tissues were detected on the greater omentum. These were removed and analysed. In those cases in which no tumor could be detected, the entire greater omentum was analysed.

In order to determine whether the administered radio activity was excreted, the urine and expired $\mathrm{CO}_{2}$ 
TABLE VI

Specific Activities (c.p.m. / $\mu$ M; of nucleic acid thymine, guanine and adenine isolated from Novikoff hepatoma, at daily intervals of growth, $110,100 \mathrm{c} . \mathrm{p} . \mathrm{m}$. of $\mathrm{Cl} 4$ injected in donor tumor suspension.

\begin{tabular}{|c|c|c|c|c|c|}
\hline \multirow{3}{*}{$\begin{array}{l}\text { Hours of } \\
\text { Iumor } \\
\text { Growth }\end{array}$} & \multicolumn{5}{|c|}{ Specific Activity c.n.m. $/ \mu M$} \\
\hline & \multicolumn{3}{|c|}{ DNA } & \multicolumn{2}{|c|}{$\overline{\mathrm{RNA}}$} \\
\hline & thymine & guan ine & adenine & guanine & adenine \\
\hline $\begin{array}{l}0 \text { (Donor } \\
\text { suspen- } \\
\text { sion) }\end{array}$ & 8,280 & 12,400 & 7,080 & 15,660 & 12,020 \\
\hline 24 & $\mathrm{NS}_{\mathrm{NS}}^{*}$ & $\begin{array}{l}\text { NS } \\
\text { NS }\end{array}$ & 249 & $\frac{175}{306}$ & $\begin{array}{l}\text { NS } \\
\text { NS }\end{array}$ \\
\hline 72 & NS & NS & NS & NS & NS \\
\hline 96 & NS & NS & NS & NS & 221 \\
\hline
\end{tabular}

* NS - counts not significant

TABLE VII

Radio activity excreted in urine during intraperitoneal growth of radio active Novikoff hepatoma, $110,100 \mathrm{c} \cdot \mathrm{p} . \mathrm{m}$. of $\mathrm{C}^{14}$ injected in donor tumor suspension.

\begin{tabular}{|c|c|c|c|}
\hline $\begin{array}{l}\text { Period of } \\
\text { Tumor Growth } \\
\text { (hours) }\end{array}$ & $\begin{array}{l}\text { Number of } \\
\text { Groups } \\
\text { Averaged }\end{array}$ & $\begin{array}{l}\text { C.p.m. } \\
\text { excreted } \\
\text { in urine }\end{array}$ & $\begin{array}{c}\% \text { Total } \\
\text { c.p.m. } \\
\text { injected }\end{array}$ \\
\hline $\begin{array}{r}0=12 \\
12=24 \\
24=36 \\
36=48 \\
48=72 \\
72-96\end{array}$ & $\begin{array}{l}4 \\
4 \\
3 \\
3 \\
2 \\
1\end{array}$ & $\begin{array}{r}24,358 \\
2,458 \\
1,542 \\
\text { Trace } \\
\text { Trace } \\
\text { Trace }\end{array}$ & $\begin{array}{c}22.2 \\
2.2 \\
1.4 \\
= \\
=\end{array}$ \\
\hline & & \multicolumn{2}{|c|}{ Total 25.8} \\
\hline
\end{tabular}


were analysed. The expired $\mathrm{CO}_{2}$ was collected from some of the groups. In all cases insignificant amounts of radio activity were found in the $\mathrm{CO}_{2}$ expired during the 4 days of tumor growth. This is in agreement with the aforementioned results which indicated that the donor suspension contained little or no formate-C ${ }^{14}$. However considerable radio activity was found in the urine samples (Table VII), particularly in those excreted during the first 12 hours of tumor growth. It will be noted that approximately $25 \%$ of the administered $\mathrm{C}^{14}$ has been excreted during the 36 hours immediately following the injection of the radio active tumor suspension.

In view of the lack of significant counts obtained for the nucleic acid fractions of the growing tumor, as well as those obtained from the expired $\mathrm{CO}_{2}$, it is planned to repeat this experiment using a donor tumor suspension with a considerably higher radio activity. 


\section{DISCUSSION}

The experiments described in this thesis were undertaken in order to study, in vivo, the nucleic acid metabolism of neoplastic and nonneoplastic tissues. Novikoff hepatoma, which can be maintained in a transplantable form, was the neoplasm studied. The incorporation of formate-clu into the nucleic acids of this neoplasm were compared with the incorporation of formate-c $C^{14}$ into the nucleic acids of regenerating rat liver, normal tissues, and certain host tissues of rat bearing Novikoff hepatoma, regenerating liver or both of these tissues. Considering the common cell origin and rapid rates of growth of Novikoff hepatoma and regenerating rat liver, it was of interest to compare the nucleic acid metabolism in these tissues.

Several investigations $(2-12,14,15)$ have demonstrated a higher incorporation of phosphorous, formate, glycine, orotic acid and uracil into the nucleic acid fractions of tumor tissue than into normal tissue. The results reported herein are for the most part in agreement with the findings of the above investigations, for it is evident from these results that formate is more extensively utilized for nucleic acid biosynthesis in 4 th and 6 th day Novikoff hepatoma than it is in normal spleen and liver. However the high for- 
mate incorporation into the hepatoma is not specific to tumor since normal intestinal mucosa exhibits a similar degree of formate intake. This is in accord with the findings of Heidelberger et al (15) who observed that the degree of conversion of uracil into the nucleic acid pyrimidines of intestinal mucosa in vivo was similar to that of Flexner-Jobling carcinoma. Therefore a high rate of nucleic acid synthesis or turnover is not unique to neoplastic tissue. It is believed that the differences in the extent of formate incorporation into the nucleic acids of the tissues studied are related to different degrees of growth or cell renewal in these tissues. Since the cells of the intestinal mucosa are continuously being sloughed off, and replaced by new cells (69), one would anticipate finding a relatively high level of nucleic acid biosynthesis in this tissue. Furthermore the higher formate incorporation into the nucleic acids of regenerating liver than into normal resting liver is understandable in view of the greater cell multiplication in the former tissue.

It would also appear from these results that 4 th and 6 th day Novikoff hepatoma are more rapidly dividing tissues than 40 hour regenerating rat liver. However Hecht and Potter (47) found that the incor- 
poration of orotic acid-6-C 14 into the DNA of 24-30 hour regenerating rat liver was approximately twice that of 40 hour regenerating liver. Similar results were obtained by Cater, Holmes and Mee (44) on measuring the uptake of $\mathrm{p}^{32}$ into the DNA of regenerating rat 1 iver. Others have reported $(40,41$, 55-57) maximal rates of nucleic acid synthesis in regenerating rat liver at earlier stages in the regeneration than 40 hours. Therefore it is possible that the formate incorporation into the nucleic acids of 24 - 30 hour regenerating rat Iiver could approximate the uptake of formate by the nucleic acids of 4 th and 6 th day Novikof $f$ hepatoma. In contrast to the aforementioned results, Briqes, Tracy and Cohn (2) found a higher incorporation of $\mathrm{p}^{32}$ into the nucleic acids of 96 hour regenerating rat 1 iver as compared to a transplanted hepatoma. Fur thermore LePage and Heidelberger (3) observed a higher uptake of glycine$2-C^{14}$ by 63 hour regenerating rat liver as compared to 8 day-old Flexner-Jobling carcinoma transplants. In view of the low rates of nucleic acid synthesis obtained by others at approximately the 63 or 96 hour stage of rat liver regeneration, the results reported herein indicate that 4 th and 6 th day Novikoff hepatoma are more rapidly dividing tissues than the transplanted 
hepatoma of Brues and coworkers, and 8 day-old Flexner-Jobling carcinoma-transplants.

Al though the mitotic counts of Novikoff hepatoma indicated that 4 th day tumor is a more rapidly dividing tissue than 6 th day hepatoma, the formate incorporation studies do not corroborate this finding. It is evident that there is little difference in the uptake of formate $-\mathrm{C}^{14}$ by the nucleic acids of $4^{\text {th }}$ day hepatoma, as compared to 6 th day hepatoma. This apparent discrepancy could be explained on the basis of a turnover process between formate and the nucleic acids of 6 th day Novikoff hepatoma. In such a process formate incorporation into the nucleic acids would occur unassociated with cell division. Such an explanation is not justified a.t this time in view of the small number of mitotic counts and experiments performed. However Aqvist and Anderson (57) observed such a turnover process between glycine and the RNA of $9-14$ hour regenerating liver, at which time they found no net synthesis of RNA.

It is evident, from the results obtained from 4th day tumor-bearing animals, that Novikoff hepatoma has no influence on the incorporation of formate into the nucleic acids of liver and intestinal mucosa of the host. No effect of tumor on the 
incorporation of formate into the nucleic acid guanine, DNA adenine, and thymine of spleen was observed. However the relative specific activity of RNA adenine of spleen was decreased in the tumorbearing animals. The significance of this finding is not understood. Pertinent to this result it is of interest to note that others (24) have observed a drop in nucleic acid concentration of host tissues of rats bearing Walker carcinoma. However it appears that the presence of Novikoff hepatoma has no influence on the de novo biosynthesis of the nucleic acids of the host tissues of the rat. In agreement with this is the finding of LePage and Heidelberger (3) who found no difference in glycine incorporation into the nucleic acids of normal liver as compared to livers of rats bearing Flexner-Jobling carcinoma. On the other hand Tyner and coworkers (5) found that the presence of Flexner-Jobling carcinoma did stimulate the uptake of $\mathrm{p}^{32}$ into the DNA nucleotides of rat 1 iver. Kelly and associates $(25-28)$ have observed an in-

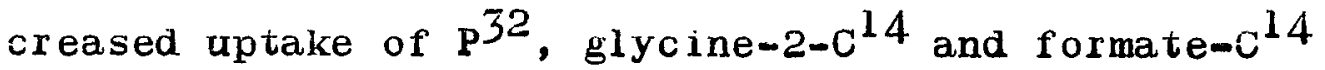
into the DNA of host tissues of tumorabearing rats and mice. Others have reported $(29-32)$ that several preformed purine precursors were utilized to a greater degree by the nucleic acids of host tissues of tumor- 
bearing animals than the nucleic acids of tissues of normal animals. In view of the results of others obtained with several tumors, it is significant that Novikoff hepatoma has little or no effect on the nucleic acid metabolism of other tissues of the host. However until further studies, using a variety of precursors, are performed, it is not possible to consider Novikoff hepatoma as a unique tumor in this regard.

No evidence was obtained to support the concept of the release of a "growth promoting" agent from the regenerating liver of rats as proposed by others (58). The de novo biosynthesis of nucleic acids by spleen and intestinal mucosa was not altered by the presence of regenerating 1 iver in the animal. Furthermore neither Novikoff hepatoma nor regenerating liver had an effect on the uptake of formate into the nucleic acids of one another in partially hepatectomized-tumorbearing rats. Similar results had been obtained with glycine by LePage and Heidelberger (3) using partially hepatectomized rats bearing subcutaneous transplants of Flexner-Jobling carcinoma. However these finding do not agree with the growth experiments of Paschkis et al (58) or with the observations of Balis and associates (6l). The latter investigators found a stimulation in the uptake of several preformed precursors into the purines 
of tissues of partially hepatectomized hamsters. Furthermore they observed an increased incorporation of adenine into the tumor of partially hepatectomized hamsters bearing a human tumor. On the other hand the utilization of glycine by the human tumor in the partially hepatectomized hamster was reduced. These results would suggest that the presence of regenerating liver, stimulates the preformed pathway of nucleic acid biosynthesis in tumor, but depresses the de novo pathway. However the results obtained from this study using partially hepatectomized rats bearing Novikoff hepatoma indicate no effect of regenerating liver on the de novo biosynthesis of the nucleic acids of the hepatoma.

Although there is a slight decrease in the relative specific activity of most of the nucleic acid purines and thymine of the tissues in: the partially hepatectomized-tumor-bearing rats, the significance of these findings is doubtful in view of the limited number of experiments performed. It would seem that the combination of regenerating 1 iver and Novikof hepatoma in one rat does not alter the nucleic acid metabolism of the host's spleen or intestinal mucosa. Similar results were obtained by Bal is and coworkers (61) in partially hepatectomizedtumor-bearing hamsters. The results of the latter 
investigators also indicated that tumor has no eifect on the nucleic acid metabolism of regenerating liver, in the comined hepatectomized-tumorbearing hamsters. The results of this study are in agreement, for it is observed that Novikoff hepatoma does not alter the incorporation of formate into the nucleic acids of regenerating liver in partially hepatectomized-tumor-bearing rats.

As stated, the finding that regenerating rat 1 iver does not affect the nucleic acid metabol ism of Novikoff hepatoma, is in contrast to the results obtained by Balis and coworkers (61). This difference could be attributed to differences in the metabolism. of the human tumor used by Bal is and associates and the Novikoff hepatoma used in these studies. Fur thermore the different results could occur because of the species difference between hamsters and rats. It is of interest, therefore, to note the observation of Balis and associates (61), that preliminary. data from similar experiments with other tumors and animals indicated that the effects of regenerating liver on tumor were not always found.

On considering the rapid excretion of radio activity in the expired $\mathrm{CO}_{2}$ of the rats bearing either regenerating liver or Novikoff hepatoma or both of these tissues, it is evident that the available for- 
mate- $\mathrm{C}^{14}$ in the tissues of these animals is rapidly depleted during the 24 hours immediately following the formate-cl4 injection. Similar losses of 40 $60 \%$ of the administered radio activity have been obtained by others $(68,70)$ using normal animals. Therefore it appears that the excretion of formate is not significantly altered by the presence of one or two additional rapidly growing tissues, which place a further demand on the "pool" of available formate. The significance of these findings is not understood, al though it is possible that the formate "pool" of the rats is large enough that additional dew mands on the supply of formate would not be manifested in significant alterations in the excretion of $\mathrm{CO}_{2}$. Although urinary formate determinations were not performed the results indicate that formate-C ${ }^{14}$ was excreted in the urine because of the difference observed in the radio activity of alkaline and acidic urine. Nevertheless a significant amount of the administered radio activity was recovered in the urine. This finding is in accord with the essential position of formate in many metabolic pathways. Urea, allantoin and creatinine are but a few of the urinary constituents which could account for radio activity in the urine of rats, following the administration of $\mathrm{C}^{14}$.

The observation that the incorporation of formate into the nucleic acids of regenerating liver and 
Novikoff hepatoma was not altered in partially hepatectomized-tumor-bearing rats was considered as an indication of autonomy in the nucleic acid metabolism of these tissues. The autonomous growth of mal ignancies is frequently observed. Therefore it was of interest to determine the incorporation of radio activity into regenerating liver in tumorbearing animals which had been injected with formate$\mathrm{C}^{14}$ prior to the partial hepatectomy. It is evident that the nucleic acids of the regenerating livers in these animals incorporated approximately the same amount of radio activity as the non-regenerating livers of the tumor-bearing controls. However the livers of the control animals were able to incorporate radio activity during the period immediately following the formate- $\mathrm{C}^{14}$ injection, at which time the concentration of available formate-c ${ }^{14}$ was relatively high. On the other hand the regenerating liver was first able to incorporate radio activity 24 hours after the formate$\mathrm{C}^{14}$ was injected at which time approximately $50 \%$ of the radio activity had been excreted. Therefore the radio activity detected in the nucleic acids of the regenerating liver could be derived from the formate already incorporated into the remnant at the time of the hepatectomy, as well as the formate incorporated by the regenerating liver. In view of the low relative specific acti- 
vities obtained for the nucleic acid purines and thymine of the regenerating liver, it would appear that there is little available formate $-\mathrm{C}^{14}$ present in the rat during the period 24 to 72 hours after the subcutaneous injection of formate-cl4. The data also indicate that the nucleic acids of regenerating I iver do not incorporate radio activity from indirect sources of radio activity in formate- $\mathrm{C}^{14}$-injected animals. This is indicated by the results obtained for tumor, spleen and intestinal mucosa which demonstrate that regenerating liver has not withdrawn radio activity from the nucleic acids of these tissues. Little or no difference is noted in the relative specific activities of the nucleic acid purines and thymine of tumor and intestinal mucosa, of the tumor-bearing animals with delayed hepatectomies, as compared to the corresponding fractions of the tumor-bearing control animals. There is also no difference in the relative specific activities of corresponding DNA bases of spleen of the hepatectomized-tumor-bearing animals as compared to the control animals. However there is a decrease in the relative specific activity of the RNA guanine of spleen of the hepatectomized group as compared to the control group. It is not possible to compare the corresponding adenine fractions, but it is noted that the RNA adenine of the 
of the control group is relatively high. The significance of these findings is not understood. However on the basis of these results it would appear that regenerating liver does not grow at the expense of other tissues.

The results of the experiment carried out to determine the distribution of radio activity following the transplantation of radio active Novikof' hepatoma are difficult to assess, because many of the determinations did not yield significant data. However it is evident that approximately $20 \%$ of the administered radio activity is excreted in the urine during the first 12 hours of tumor growth. The results also indicate that there was litile free formate-c ${ }^{14}$ in the donor tumor suspension. It is assumed that the radio activity present in the urine is the result of the catabolism of compounds which had incorporated formate, and not the result of formate excretion. Therefore urinary constituents such as allantoin, $\beta$ ureidoisobutyrate, $\beta$ aminoisobutyrate, creatinine, areatine, methionine and serine could become radio active following the intraperitoneal injection of a tumor suspension labelled with $\mathrm{c}^{14}$. In agreement with the rapid appearance of radio activity in the urine, is the finding of negligible or insignificant specific activities in the nucleic acids of the tumor obtained after 24 hours of intraperitoneal 
growth. I'his would indicate a rapid turnover of both RNA and DNA of the injected Novikoff bepatoma during the first 24 hours of growth. However the nucleic acid of the donor tumor suspension contained only about $2 \%$ of the total radio activity in the suspension. Therefore it is difficult to assess the degree of turnover from these results because of the lack of significant data. Furthermore it is difficult to obtain adequate amounts of tumor, separate from greater omentum, 24 and 48 hours after transplantation, and therefore the data shown for tumor obtained at these times, may not be representative of "pure" tumor tissue. Nevertheless it is felt that it would be advantageous to repeat this experiment using a wore radio active donor tumor suspension.

The results of these studies of the nucleic acid metabolism of regenerating rat liver, Novikoff hepatoma, and host tissues of rats containing one or both of these tissues, are not completely in accord with the results obtained by others. However, in order to obtain statistically significant data the experiments should be repeated. It would also be of interest to perform similar studies using a variety of labelled nucleic acid precursors. Similar studies performed on large groups of mice should also be considered. 


\section{SUMMARY}

1. A study has been made of the incorporation in vivo of formate-c $\mathrm{c}^{14}$ into the nucleic acids of regenerating rat liver and Novikoff hepatoma. Regenerating liver was obtained 40 hours after partial hepatectomy. Novikoff hepatoma was obtained on the 4 th or 6 th day after transplantation. The influence of one or both of these tissues on the host tissues has also been examined.

2. The incorporation of formate into the nucleic acid purines and thymine of 4 th day Novikoff hepatoma and regenerating rat 1 iver did not appear to be significantly influenced by the simultaneous presence of both of these rapidly dividing tissues in one animal. These findings have been discussed in the light of evidence which indicated that approximately 50 per cent of the administered radio-activity was excreted in the urine and $\mathrm{CO}_{2}$.

3. Regenerating rat $I$ iver and 4 th day Novikof $f$ hepatoma had no significant effect on the formate incorporas tion into the nucleic acids of the spleen and intestinal mucosa of the host animal bearing one or both of these tissues.

4. The relative specific activities of the nucleic acid bases of 40 hour regenerating rat liver were greater than the relative specific activities of correspon- 
ding fractions of normal 1 iver. On the other hand the uptake of formate by $4^{\text {th }}$ and 6 th day Novikoff hepatoma was greater than 40 hour regenerating rat liver.

5. The results of mitotic counts indicated a maxiinal mitotic frequency in 4 th day hepatoma. How ever the nucleic acids of 4 th and 6 th day Novikoff hepatoma incorporate formate to approximately the same extent.

6. In a preliminary experiment a radioactive suspension of Novikoff hepatoma was transplanted into a group of rats. Negligible or insignificant specific activities were obtained for the nucleic acid bases of the tumor after 24 hours of growth. Approximately 20 per cent of the administered radioactivity was excreted in the urine during this period. Although formate analyses were not perw formed, preliminary experiments indicated that no "free" formate-cl4 was present in the donor suspension. The significance of these findings has been discussed.

7. The results obtained from these experiments have been discussed in relation to the findings of others. 


\section{BIBLIOGRAPHY}

1. Novikoff, A. B., Cancer Research, 17, 1010 (1957).

2. Brues, A. M., Tracy, M. M., and Cohn, W. E., J. Biol. Chem. , 155, 619, (1944).

3. LePage, G.A., and Heidelberger, C., J. Biol. Chem., 188, 593, (1951).

4. LePage, G.A., Cancer Research, 13, 178, (1953).

5. Tyner, E.P., Heidelberger, C., and LePage, G.A., Cancer Research, 13,.186, (1953).

6. LePage, G.A., Potter, V.R., Busch, H., Heidel berger, C., and'Hur lbert, R.B.', Cancer Résearch, 12, 153 , (1952).

7. Tyner, E.P., Heidelber ger, C., and LePage, G.A., Cancer Research, 12, 158, (1952).

8. Reddy, D.V.N., Breiger, H., and Orchen, M., Cancer Research, 17, 677, (1957).

9. Wells, W., and Winzler, R.J., Federation Proc., 15, $382,(1956)$.

10. Tuttle, L.W., Erf, L.A., and Lawrence, J.A., J. Clin. Invest., 20, 57, (1941).

11. Weed, L.L., and Wilson, D.W., J. Biol. Chem., 189, 435, (1951).

12. Weed, L.L., Cancer Research, 11, 470, (1951).

13. Potter, V.R., and Hurlbert, R.B., J. Biol. Chem., 195, $257,(1952)$.

14. Rutman, R.J., Cantarow, A., and Paschkis, K. E., Cancer Research, 14, 119, (1954).

15. Heidelber ger, C. , Liebman, K.C., Harbers, E., and Bhargava, P.M., Cancer Research, 17, 399, (1957).

16. Graff, S., Engelman, M., Gillespie, H.B., and Graff, A.M., Cancer Research, $11,388,(1951)$.

17. Cerecedo, L. R., Reddy, D.V.N., Pircio, A., Lombardo, M.E., and Travers, J.J., Froc. Soc. Exper. Biol. \&.Med., 78, 683, (1951). 
18. Cerecedo, L.R., Reddy, D.V.N., Lombardo, M.E., McCarthy, P.E., and Travers, J.J., Proc. Soc. Exper. Biol. \& Med., 80, 723, (1952).

19. Lombardo, M.E., Reddy, D.V.N., McCarthy, P., Singer, E., and Cerecedo, L.R., Federation Proc., 11 , 250, (1952).

20. Lombardo, M.E., Travers, J.J., and Cerecedo, L.R., J. Biol. Chem., 195, 43, (1952).

21. Reddy, D.V.N., and Cerecedo, L.R., Federation Proc., $\underline{10}, 236,(1951)$.

22. Reddy, D.V.N., and Cerecedo, L.R., J. Biol. Chem., 192, 57, (1951).

23. Lombardo, M.E., Cerecedo, L.R., and Reddy, D.V.N., J. Biol. Chem., 202, 97, (1953).

24. Bresnick, E., and Cerecedo, L.R., J: Biol. Chem., 225, 297, (1957).

25. Kelly, L.S. Science. 111, 222, (1950).

26. Kelly, L.S., Payne, A.H., White, M.R., and Jones, H.B., Cancer Research, 11, 694, (1951).

27. Payne, A.H., Kelly, L.S., and White, M.R., Cancer Research, 12,65, (1952).

28. Payne, A.H., Kelly, L.S., Beach, L., and Jones, H.B., Cancer Research, 12, 426, (1952).

29. Way, J.L., Mandel, H.G. and Smith, P.K., Cancer Research, 14, 812, (1954).

30. Griffin, A.C., Tex. Rep. Biol. \& Med., 15, 161, (1957).

31. Bal is, M.E., Van Praag, D., and Brown, G. B., Cancer Research, 15, 673, (1955).

32. Bal is, M.E., Van Praag, D., and Aezen, F., Cancer Research, 16, 628, (1956).

33. Annau, E., Manzinelli, A., and Roth, A., Cancer Research, 11, 304, (1951).

34. Malmgren, R.A., Cancer Research, 16, 232, (1956).

35. Fishback, F.C., Arch. Path., 1, 955, (1929).. 
36. Higgins, G.M., and Anderson, R.M., Arch. Path., 12, $186,(1931)$.

37. Erues, A.M., Drury, D.R.,and Brues, M.C., Arch. Path., 22, 658, (1936).

38. Brues, A.M., Tracy, M.M., Cohn, W.E., J. Biol. Chem., 155, 619, (1944).

39. Bergstrand, A., Eliasson, N.A., Hammarsten, E, , Norberg, B., Reichard, P., and Ubisch, A.V., Cold Spring Harbor Symp., Quant. Biol., 13, 22, (1948).

40. El iasson, N.A., Hammarsten, E., Feichard, P., and Aqvist, S', Acta. Chem. Scand., 5, 431, (1951).

41. Johnson, R.M., and Albert, S., Arch. Biochem., 35 , $340,(1952)$.

42. Nygaard, $0 .$, and Rusch, H.P., Cancer Research, 15, 240 , (1955).

43. Daoust, R., LebI ond, C.P., Nadler, N.J., and Enesco, M., J. Biol. Chem., 221, 727, (1956).

44. Cater, D.B., Holmes, B.E., and Mee, L.K., Acta Radiol., 46, 655, (1956).

45. Jardetzky, C.D., Barnum, C.P., and Vermund, H., J. Biol. Chem., 222, 421, (1956).

46. Hecht, L.I., and Potter, V.R., Federation Proc., 15, 271, (1956).

47. Hecht, L.I., and Potter, V.R., Cancer Research, 16, $988,(1956)$.

48. Takagi, Y., Hecht, L.I., and Potter, V.R., Cancer Research, 16, 994, (1956).

49. Hecht, L.I., and Potter, V.R., Cancer Research, 16, 999, (1956).

50. Jardetzky, C.D., and Barnum, C.P., Arch. Biochem. \& Biophys., 67, 350, (1957).

51. Kelly, L.S., Hirsch, J.D., Beach, G., and Palmer, W., Cancer Research, 17, 117, (1957).

52. Barnum, C.P., Jardetzky, C.D., and Halberg, F., Tex. Rep. Biol. \& Med., 15, 134, (1957). 
53. Schneider, J.H., and Potter, V.R., Cancer Research, 17, 701 , (1957).

54. Price, J.M., and Laird, A.K., Cancer Research, 10, $650,(1950)$.

55. Hammersten, E., Aqvist, S., Anderson, E.P., Eliasson, N.A., Thorell, B., Acta. Chem. Scand., 10, 1568, (1956).

56. Anderson, E.P. and Aqvist, S., Acta. Chem. Scand., 10, $1576,(1956)$.

57. Aqvist, S., and Anderson, E.P., Acta. Chem. Scand., 10, $1583,(1956)$.

58. Paschkis, K.E., Cantarow, A., Stasney, J., and Hobbs, J.H., Cancer Research, 15, 519, (1955).

59. Bucher, N.L.R., Scott, J.F., and Aub., J.C., Cancer Research, 11, 457, (1951).

60. Wennecker, A.S., Sussman, N., Proc. Soc. Exper. Biol. \& Med., 26, 683, (1951).

61. Balis, M.E., Van Praag, 0., and Brown, G.B., Cancer Research, 16,632, (1956).

62. Jaenicke, L., Biochim. et Biophys. Acta. 17, 588, (1955).

63. Greenberg, G.R., Jaenicke, L., and Silverman, M., Biochim. et Biophys. Acta. 17, 589, (1955).

64. Lebl ond, C.P., and Walker, B.E., Physiol. Rev., 36, 255, (1956).

65. Zbarsky, S.H., and Wright, W.D., Can. J. Med. Sci., 31, 151, (1953).

66. Marshak, A., and Vogel, H.J., J. Biol. Chem., 189, 597, (1951).

67. Personal communication from Dr. S. H. Zbarsky.

68. Zbarsky, S.H., Findlay, S., Scrimgeour, K.G., and

Nixon, J.C., Progress Report to the National

Cancer Institute of Canada, December 15, 1956. 
69. Stevens, C.E., Daoust, R., and Lebl ond, C.P., J. Biol. Chem., 202, 177, (1953).

70. Friedmann, B., Nakada, H. I., and We inhouse, S., J. Biol. Chem. 210, 413, (1954). 